\title{
Optimization of the Cytotoxic Activity of Three Streptomyces Strains Isolated from Guaviare River Sediments (Colombia, South America)
}

\author{
Laura Ramirez-Rodriguez $(\mathbb{D}$, Boghos Stepanian-Martinez $(\mathbb{D}$, \\ Maria Morales-Gonzalez, and Luis Diaz \\ Facultad de Ingenieria, Universidad de La Sabana, Campus del Puente del Comun, Km 7 Autopista Norte de Bogotá, Chia, Colombia \\ Correspondence should be addressed to Luis Diaz; luisdb@unisabana.edu.co
}

Received 23 March 2018; Revised 24 May 2018; Accepted 12 June 2018; Published 19 July 2018

Academic Editor: Wen-Jun Li

Copyright (C) 2018 Laura Ramirez-Rodriguez et al. This is an open access article distributed under the Creative Commons Attribution License, which permits unrestricted use, distribution, and reproduction in any medium, provided the original work is properly cited.

\begin{abstract}
Three Streptomyces strains isolated from Guaviare sediments (Colombia, South America) with cytotoxic activity against prostate cancer (PC3), breast cancer (MDA-MB-231), and lung cancer (A549) line cells were studied. The present investigation reveals the enhancement of the cytotoxic activity evaluating different values of $\mathrm{pH}$, carbon sources (sucrose, glucose, xylose, maltose, and starch), and nitrogen sources (malt extract, yeast extract, meat extract, peptone, and potassium nitrate). Based on the response surface methodology, the isolates Streptomyces aburaviensis (73) had the maximum activity for lung cancer $\left(\mathrm{IC}_{50}=25.00 \pm 1.86 \mathrm{ppm}\right)$ with $4 \%$ of yeast extract, $3 \%$ of starch, and a $\mathrm{pH}$ value of 7 . Streptomyces gramineus (386) had the maximum activity against prostate cancer $\left(\mathrm{IC}_{50}=6.14 \pm 2.07 \mathrm{ppm}\right.$ ) with $5 \%$ of malt extract, $3 \%$ of glucose, and a pH value of 6 . Finally, Streptomyces psammoticus (519) had the maximum activity against breast cancer $\left(\mathrm{IC}_{50}=35.53 \pm 2.71 \mathrm{ppm}\right)$ with $1 \%$ of yeast extract, $4 \%$ of starch, and a pH 8 . The results suggest that the ethyl acetate extracts from isolates Streptomyces aburaviensis (73), Streptomyces gramineus (386), and Streptomyces psammoticus (519) have a potential for use in pharmaceuticals as cytotoxic agents.
\end{abstract}

\section{Introduction}

Cancer is a disease that has great relevance today because it is one of the most serious human health problems in the world [1]. In 2018, 1,735,350 new cancer cases and 609,640 cancer deaths are projected to occur in the United States [2]. The most common types of cancers in 2017 were prostate with $19 \%$ and lung and bronchus cancer with $14 \%$ for men [3]. Siegel et al. [2] state that, for women, the most commonly diagnosed cancers are breast, lung and bronchus, and colorectum; which collectively represent one-half of all cases. The lifetime probability of being diagnosed with invasive cancer is higher for men (39.7\%) than for women (37.6). The American Cancer Society states that cancer occurs when there is uncontrolled cell growth and spread of abnormal cells caused by external factors, such as inherited genetic mutations, hormones, and immune conditions [3]. Cancer is treated with surgery, radiation, chemotherapy, hormone therapy, immune therapy, and targeted therapy [4]. Chemotherapy is one of the most effective antitumor treatments, but this therapy needs a new active compound as the major sources of natural products with anticancer activity are microbes [5]. Maskey et al. indicate that Actinobacteria is famous as a great source of antitumor compounds, as cited in [6], mainly Streptomyces sp. There are several anticancer drugs derived from Streptomyces sp. like Proximicin A, B, and C, Daunomycin, Drimentine G, Indotertine $\mathrm{B}$, Bleomycin, and Benzastatins that are already in clinical use [6]. Streptomyces spp. are Gram positive filamentous, sporulating bacteria with DNA rich in $\mathrm{G}+\mathrm{C}$ content [7]; they have been isolated in major part from soil and aquatic habitats like rivers which have been poorly explored as a source of Streptomyces spp. with biological activity (antibacterial, antifungal, antitumor, and antioxidant) [8]. These bacteria are the major source of bioactive compounds since they shelter different gene clusters, thus producing different compounds with diverse chemical backbones [9]. 
Most of these compounds are secreted in the broth and can be extracted with organic solvents [10]. The aim of this study is to investigate the cytotoxic activity (against PC3, MDA-MB231, and A549 cancer cell lines) of extracts from Streptomyces broths isolated from a Colombian river, establishing the best conditions of carbon source, nitrogen source, and $\mathrm{pH}$.

\section{Materials and Methods}

2.1. Streptomyces Strains and Their Maintenance. A total of forty Actinobacterial strains were selected based on their antimicrobial activity from the previously described collection of 275 isolates collected from two different locations in the Guaviare river, Colombia $\left(2^{\circ} 34^{\prime} 51.6^{\prime \prime} \mathrm{N} 72^{\circ} 41^{\prime} 34.7^{\prime \prime} \mathrm{W}\right.$ and $2^{\circ} 34^{\prime} 51.4^{\prime \prime} \mathrm{N} 72^{\circ} 39^{\prime} 53.6^{\prime \prime} \mathrm{W}$ ) [8]. Morphological parameters such as aerial and substrate mycelium arrangements were carried out on ISP 3 medium as described in Bergey's Manual of Systematic Bacteriology [11] and by Shirling and Gottlieb [12]. The spore mass and mycelium of the pure isolate were stored at $-80^{\circ} \mathrm{C}$ as glycerol suspension $(40 \%$, v/v) for further analysis.

\subsection{Preparation of Active Organic Extracts. Streptomyces} strains were inoculated in $50 \mathrm{~mL}$ Erlenmeyer flask containing $10 \mathrm{~mL}$ of ISP $2(8.0 \mathrm{~g}$ of glucose, $10.0 \mathrm{~g}$ of malt extract, and $4.0 \mathrm{~g}$ of yeast extract, $\mathrm{pH} 7.2 \pm 2^{\circ} \mathrm{C}$ ) for seven days at $30^{\circ} \mathrm{C}$ under continues shaking $(200 \mathrm{rpm})$ [13], and the medium was sterilized by autoclaving at $121^{\circ} \mathrm{C}$ for $15 \mathrm{~min}$ prior to experiment [14]. Further, equal volume (1:1) of ethyl acetate was added and mixed by vigorous shaking (200 rpm). The organic phase was collected, washed with three volumes of water, and evaporated to dryness. The extract was suspended in phosphate buffered saline (PBS) at a concentration of 1000 ppm $[15,16]$.

2.3. Cytotoxicity Assay. Human A549 lung adenocarcinoma cancer cell line (ATCC ${ }^{\circledR}$ CCL-185), PC3 adenocarcinoma prostate cancer cell line (ATCC CRL-7934), and L929 mouse fibroblasts (ATCC CRL-6364) were grown as monolayer culture in DMEM medium $(10 \%(\mathrm{v} / \mathrm{v})$ with fetal bovine serum, $1 \%(\mathrm{v} / \mathrm{v})$ penicillin, and $1 \%(\mathrm{v} / \mathrm{v})$ streptomycin). The breast cancer cell line MDA-MB-231 (ATCC HTB-26) was incubated in RPMI (10\% (v/v) with fetal bovine serum, $1 \%$ $(\mathrm{v} / \mathrm{v})$ penicillin, and $1 \%(\mathrm{v} / \mathrm{v})$ streptomycin). The cells were maintained in a humidified atmosphere with $5 \% \mathrm{CO}_{2}$ at $37^{\circ} \mathrm{C}$ [17]. Briefly, $100 \mu \mathrm{L}$ of cell suspension was inoculated to $96-$ well plates with a density of $5 \times 10^{3}$ cells/well and cultured for $24 \mathrm{~h}$. After that, culture medium was replaced with $100 \mu \mathrm{L}$ serum-free medium containing various concentrations (10, 25, 50, 100, and $200 \mathrm{ppm}$ ) of Streptomyces broth extracts, each extract was tested in triplicate based on Ravikumar et al. [16]. Doxorubicin (1-25 ppm) was used as the cytotoxic positive control, medium supplemented with bovine serum albumin $1 \%(\mathrm{w} / \mathrm{v})$ as negative control (100\% survival), and free medium containing PBS as blank [18].

The cell viability was assessed by adding $10 \mu \mathrm{l}$ of MTT $(5 \mathrm{mg} / \mathrm{mL})$ per well, after $48 \mathrm{~h}$ of incubation, and the plates were incubated with $5 \%$ of $\mathrm{CO}_{2}$ at $37^{\circ} \mathrm{C}$ for $3 \mathrm{~h}$. The formazan crystals formed in the cells were dissolved with $100 \mu \mathrm{L}$ of DMSO measured at $570 \mathrm{~nm}$ using a microplate reader (iMark $^{T M}$ Microplate Reader) [19]. Cytotoxicity of each sample was expressed as an $\mathrm{IC}_{50}$ value. The $\mathrm{IC}_{50}$ value is the concentration of the test sample that causes $50 \%$ inhibition of cell growth averaged from three replicate experiments [15].

2.4. Effect of Different Carbon and Nitrogen Sources on Cytotoxic Activity. To improve the cytotoxic activity of tree Streptomyces strains with the highest cytotoxic activity (73, 386, and 519), preliminary experiments of carbon and nitrogen sources were carried out. Streptomyces strains were grown in 12 well microplates with $5 \mathrm{~mL}$ basal agar $\left(\left(\mathrm{NH}_{4}\right)_{2} \mathrm{SO}_{4}\right.$ $2.64 \mathrm{~g} / \mathrm{L}, \mathrm{KH}_{2} \mathrm{PO}_{4} 2.38 \mathrm{~g} / \mathrm{L}, \mathrm{K}_{2} \mathrm{HPO}_{4} 4.31 \mathrm{~g} / \mathrm{L}, \mathrm{MgSO}_{4} \times 7 \mathrm{H}_{2} \mathrm{O}$ $1.0 \mathrm{~g} / \mathrm{L})$ and $1.0 \mathrm{ml} / \mathrm{L}$ trace element solution $\left(\mathrm{CuSO}_{4} \times 5 \mathrm{H}_{2} \mathrm{O}\right.$ $0.64 \mathrm{~g} / \mathrm{L}, \mathrm{FeSO}_{4} \times 7 \mathrm{H}_{2} \mathrm{O} 0.11 \mathrm{~g} / \mathrm{L}, \mathrm{ZnSO}_{4} \times 7 \mathrm{H}_{2} \mathrm{O} 0.15 \mathrm{~g} / \mathrm{L}$, $\mathrm{MnCl}_{2} \times 4 \mathrm{H}_{2} \mathrm{O}$ ), supplemented with $0.8 \%$ (w/v) of carbon source: lactose, galactose, ribose, xylose, maltose, starch, sucrose, fructose, and carboxymethylcellulose, with glucose as positive control and no carbon source as negative control [8]. Nitrogen sources were evaluated in the same way at the same conditions at $1.4 \%(\mathrm{w} / \mathrm{v})$ : L-asparagine, L-glutamine, proline, ammonium sulphate, meat extract, yeast extract, potassium nitrate, peptone, and malt extract [18]. The experiments were performed for 7 days, $\mathrm{pH} \mathrm{7,} 200 \mathrm{rpm}$, and $30^{\circ} \mathrm{C}$; the results demonstrated that the five carbon sources that enhanced the cytotoxic activity of Streptomyces strains were glucose, xylose, maltose, starch, and sucrose. Likewise, the nitrogen sources selected were meat extract, yeast extract, potassium nitrate, peptone, and malt extract [20].

2.5. Media Optimization. The influence of environmental and nutritional conditions in growth culture, such as initial $\mathrm{pH}(6-8)$ and carbon and nitrogen sources concentrations $(0,1-5 \% \mathrm{w} / \mathrm{v})$ [21], on the cytotoxic activity was evaluated using a face central composite design (FCCD), evaluating 15 trials with five levels for each factor.

The experimental results of FCCD were statistically studied by analysis of variance (ANOVA). All the experiments were done in triplicate, and the average of the cytotoxic activity was obtained and taken as the dependent variable or response $(Y)$. The results were fitted via the response surface regression procedure using the following second order polynomial equation [22]:

$$
Y=\beta_{0}+\sum_{i=1}^{n} \beta_{i} x_{i}+\sum_{i=1}^{n-1} \sum_{j=i+1}^{n} \beta_{i j} x_{i} x_{j}+\sum_{i=1}^{n} \beta_{i i} x_{i}^{2}
$$

in which $Y$ is the predicted response, $\beta_{0}$ is the regression coefficients, $\beta_{i}$ is the linear coefficient, $\beta_{i i}$ is the quadratic coefficients, $\beta_{i j}$ is the interaction coefficients, and $X i$ is the coded levels of independent variables [20].

2.6. Molecular Characterization. Total genomic DNA was isolated using the phenol chloroform method [23]. PCR amplification of $16 \mathrm{~S}$ rRNA gene locus was conducted using primers 27F ( $5^{\prime}$-AGAGTTTGATCMTGGCTCAG- $\left.3^{\prime}\right)$ and 1492R ( $5^{\prime}$ - TACGGYTACCTTGTTACGACTT-3'). The PCR product was detected by agarose gel electrophoresis [8]. 
PCR thermal cycling is described elsewhere [24]. PCR products were sequenced by Macrogen (Korea). Sequences were assembled using the CLC Main Workbench 7.0 program and were aligned using SINA. The sequences were subjected to homology search using EzTaxon system (https://blast.ncbi.nlm.nih.gov/Blast.cgi) and the BLAST program of the National Centre for Biotechnology Information (NCBI) [18].

2.7. LC-MS Analysis. The dry extracts were dissolved in methanol and were subjected to LC-MS analysis on LCMS2020 (Shimadzu Corp, Japan) system equipped with a single quadrupole analyser and an electrospray ion source (ESI). The analysis was done using a Synergi $\mathrm{RP} \mathrm{C}_{18}$ column (Phenomenex) dimension $150 \times 4.4 \mathrm{~mm}$ and film thickness of $4 \mu \mathrm{m}\left(0.7 \mathrm{~mL} / \mathrm{min}\right.$ flow rate; $30^{\circ} \mathrm{C}$ column oven temperature $)$. $0.1 \%$ formic acid in acetonitrile and $0.1 \%$ formic acid in water were used as mobile phases $\mathrm{A}$ and $\mathrm{B}$, respectively. The gradient elution was done as follows: $0 \mathrm{~min}, 10 \% \mathrm{~A} ; 3 \mathrm{~min}$, $10 \% \mathrm{~A} ; 14 \mathrm{~min}, 40 \% \mathrm{~A} ; 21 \mathrm{~min}, 70 \% \mathrm{~A} ; 25 \mathrm{~min}, 100 \% \mathrm{~A}$; $30 \mathrm{~min}, 10 \% \mathrm{~A}$. ESI was simultaneously operated in positive and negative ion mode (scan $200-800 \mathrm{~m} / \mathrm{z} ; 250^{\circ} \mathrm{C} \mathrm{CDL}$ temperature; $1.2 \mathrm{kV}$ detector voltage; $1.3 \mathrm{~L}$ min-nebulizing gas flow rate; $8.0 \mathrm{~L}$ min-drying gas flow rate) [25].

2.8. Statistical Analysis. Design Experts ${ }^{\circledR}$ v7 software was used for the experimental designs and the models were statistically studied by analysis of variance (ANOVA) applied to the established regression, with a statistical significance $(\mathrm{P}<0.05)$. The surface plots were made with Statistica ${ }^{\circledR}$ software.

\section{Results}

Forty Actinobacterial extracts at $100 \mathrm{ppm}$ were tested in the cytotoxic assay against prostate (PC3), lung (A549), and breast (MDA-MB-231) cancer lines (Table 1). Streptomyces strains 73, 386, and 519 presented the highest cytotoxic percent so that values of $\mathrm{IC}_{50}$ (Table 2) were calculated to improve their cytotoxic activity.

The Streptomyces strains 73, 386, and 519 were characterized based on colony, morphology, mycelium coloration, and pigment diffusion. The light microscopy observation of isolates on ISP 3 media showed a straight chain section with no fragmentation of the aerial mycelium. The isolates are Gram positive strains and presented spores surfaced oval shaped with short compact spirals indicating that they belong to the genus Streptomyces. [26]. Consequently, Streptomyces 73 showed an aerial and substrate mycelium, white and grey, respectively. Streptomyces 386 and 519 showed a white aerial mycelium and brown substrate mycelium with a pigment production similar to melanin (Figure 1).

3.1. Taxonomical Identification. The phylogenetic data of the $16 \mathrm{~S}$ rRNA gene sequences of three isolates were obtained aligning the nucleotides, and the representative sequences of related type strains of the genus Streptomyces were retrieved from the GenBank/EMBL/DDBJ databases using CLUSTAL$\mathrm{X}$ software [27]. Phylogenetic trees were oxconstructed with the Neighbor-Joining method [28] (Figures 2, 3, and 4) using MEGA version 6.0 [29]. The EzTaxon system (http://www.ezbiocloud.net/eztaxon) was used to calculate sequence similarities [30]. Considering that the most recent definition of a prokaryotic species based on 16S rRNA gene sequence similarity is determined by a minimum similarity of $98.7 \%$ [31], the isolate 386 was identified as Streptomyces gramineus [32] with 100\% similarly (accession number HM748598.2); the isolate 73 had close similarity with two Actinobacterial strains: Streptomyces avellaneus [33] (accession number AB184413.1, 99.77\% sequence similarity) and Streptomyces aburaviensis [34] (accession number AY999779.1, 99.77\% sequence similarity), but, according to morphological studies, the isolate 73 was identified as Streptomyces aburaviensis [35]; and the isolate 519 was identified as Streptomyces psammoticus (accession number AB184554.2, 99.77\% sequence similarity).

\subsection{Effect of Carbon and Nitrogen Sources on Cytotoxic} Activity. Five carbon and nitrogen sources were evaluated to increase the cytotoxic activity of extracts from three isolates; that is why the ISP 2 media was modified $(8.0 \mathrm{~g}$ carbon source and $14 \mathrm{~g}$ of nitrogen source); the results for carbon source are shown in Tables 3 and 4. The carbon source to which the strain Streptomyces aburaviensis (73) had the higher cytotoxic percent was starch, obtaining cytotoxic values of $91.22 \%, 83.9 \%$, and $68.1 \%$ at $100 \mathrm{ppm}$ for prostate, lung, and breast cancer. Likewise, the values of $\mathrm{IC}_{50}$ for each cell line were $50.26 \pm 2.54,26.16 \pm 3.26$, and $26.65 \pm 0.86 \mathrm{ppm}$, respectively, being more active for lung tumour cell line (A549). The strain Streptomyces gramineus (386) had the highest cytotoxic percent, with glucose as a carbon source for the PC3 tumour line and xylose for A549 and MDA-MB-231, obtaining values of $90.64 \%, 83.18 \%$, and $65.63 \%$, respectively. The strain Streptomyces gramineus (386) was more active for prostate tumour cell line (PC3) using glucose as a carbon source with an $\mathrm{IC}_{50}$ value of $11.18 \pm 3.85 \mathrm{ppm}$. Finally, the strain Streptomyces psammoticus (519) had the highest cytotoxic percent at $100 \mathrm{ppm}$ with xylose as the carbon source, obtaining values of cytotoxic percent at $100 \mathrm{ppm}$ higher than $80 \%$, and the values of $\mathrm{IC}_{50}$ were $55.80 \pm 2.96,48.58 \pm 2.39$, and $39.98 \pm 3.27 \mathrm{ppm}$ for prostate, lung, and breast cancer, respectively; this strain was more active for breast cancer (MDA-MB-231).

The results of the cytotoxic activity of different nitrogen sources in the ISP 2 broth are shown in Tables 4 and 5. The nitrogen sources that improved the cytotoxic activity for the isolate Streptomyces aburaviensis (73) were meat extract for the prostate tumour cell line and yeast extract for lung and breast cancer, obtaining cytotoxic percent of $77.14 \%, 63.45 \%$, and $75.78 \%$ at $100 \mathrm{ppm}$, respectively. The $\mathrm{IC}_{50}$ values were measured using yeast extract as a nitrogen source, and the $\mathrm{IC}_{50}$ values were $74.36 \pm 1.05,69.13 \pm 1.05$, and $45.39 \pm$ $3.06 \mathrm{ppm}$ for prostate, lung, and breast tumour cell lines. The strain Streptomyces gramineus (386) had the best cytotoxic activity with malt extract with values of cytotoxic percent higher than $50 \%$ and had the highest cytotoxic activity for the prostate tumour cell line with an $\mathrm{IC}_{50}$ value of $14.59 \pm$ $2.82 \mathrm{ppm}$. Furthermore, the strain Streptomyces psammoticus 
TABLE 1: Cytotoxic activity of forty Actinobacterial extracts against prostate (PC3), lung (A549), and breast (MDA-MB-231) cancer lines (Table 1). NA: non-activity. The results are expressed as an average \pm standard deviation $(n=3)$.

\begin{tabular}{|c|c|c|c|}
\hline \multirow{2}{*}{ Strain } & \multicolumn{3}{|c|}{ Cytotoxic Activity (\%) } \\
\hline & PC3 & MDA-MB-231 & A549 \\
\hline 4 & NA & NA & $13.05 \pm 2.08$ \\
\hline 5 & $3.11 \pm 5.21$ & $20.2 \pm 3.75$ & $13.5 \pm 5.18$ \\
\hline 11 & $3.06 \pm 3.57$ & $18.5 \pm 4.31$ & $13.1 \pm 3.57$ \\
\hline 17 & $3.85 \pm 4.12$ & $21.1 \pm 2.97$ & $6.9 \pm 2.78$ \\
\hline 18 & NA & $16.11 \pm 5.26$ & $1.5 \pm 2.35$ \\
\hline 20 & $24.24 \pm 2.78$ & NA & $10 \pm 6.43$ \\
\hline 26 & $35.44 \pm 2.97$ & $24.2 \pm 4.82$ & $4.7 \pm 2.54$ \\
\hline 28 & $50.46 \pm 3.3$ & $58.3 \pm 5.32$ & $9.9 \pm 1.59$ \\
\hline 29 & $6.98 \pm 23.65$ & $35.7 \pm 5.11$ & NA \\
\hline 30 & $18.78 \pm 2.26$ & NA & $51.5 \pm 4.72$ \\
\hline 32 & $76.5 \pm 5.82$ & $61 \pm 4.73$ & $36.21 \pm 4.62$ \\
\hline 41 & $18.57 \pm 2.49$ & $22.5 \pm 5.65$ & $37.32 \pm 3.38$ \\
\hline 42 & $16.7 \pm 3.86$ & $46.3 \pm 6.76$ & $38.2 \pm 5.33$ \\
\hline 44 & $13.48 \pm 1.27$ & $7.035 \pm 4.98$ & NA \\
\hline 48 & $15.6 \pm 5.42$ & $5.05 \pm 3.97$ & NA \\
\hline 73 & $88.21 \pm 3.85$ & $64.94 \pm 1.96$ & $75.69 \pm 2.42$ \\
\hline 83 & NA & $2.8 \pm 4.48$ & $0.7 \pm 3.85$ \\
\hline 105 & $49.2 \pm 4.21$ & $46.5 \pm 5.64$ & $56.32 \pm 3.49$ \\
\hline 159 & $15.86 \pm 2.39$ & $30.6 \pm 2.37$ & $26.9 \pm 5.32$ \\
\hline 171 & $31.94 \pm 1.76$ & $49.8 \pm 4.84$ & $24.9 \pm 4.39$ \\
\hline 194 & $2.78 \pm 3.12$ & $16 \pm 7.11$ & NA \\
\hline 239 & $30.41 \pm 6.72$ & $57.1 \pm 3.16$ & $10.5 \pm 4.61$ \\
\hline 245 & $5.74 \pm 3.21$ & $27.1 \pm 5.96$ & NA \\
\hline 259 & $34.2 \pm 3.31$ & $17.31 \pm 4.64$ & $37.02 \pm 5.83$ \\
\hline 278 & $30.93 \pm 2.98$ & $16.82 \pm 0.12$ & $57.11 \pm 4.74$ \\
\hline 294 & $16.87 \pm 4.98$ & $66.6 \pm 2.34$ & $1.46 \pm 3.76$ \\
\hline 339 & $47.41 \pm 6.27$ & $36.6 \pm 4.72$ & $3.1 \pm 5.56$ \\
\hline 363 & $27.86 \pm 3.45$ & $53.5 \pm 4.61$ & $3.5 \pm 4.42$ \\
\hline 386 & $89.73 \pm 2.07$ & $59.28 \pm 2.67$ & $78.12 \pm 3.01$ \\
\hline 389 & $15.12 \pm 4.21$ & $39.2 \pm 4.16$ & $23 \pm 5.35$ \\
\hline 424 & $7.72 \pm 3.08$ & $49.7 \pm 6.23$ & $1.6 \pm 3.78$ \\
\hline 429 & $21.12 \pm 2.73$ & $35.7 \pm 4.97$ & $1.4 \pm 3.34$ \\
\hline 431 & $30.42 \pm 4.84$ & $39.7 \pm 3.52$ & $20.21 \pm 3.16$ \\
\hline 441 & NA & NA & $39.1 \pm 4.56$ \\
\hline 452 & $2.1 \pm 3.21$ & NA & $0.8 \pm 3.42$ \\
\hline 461 & NA & $5.5 \pm 6.95$ & $7 \pm 4.21$ \\
\hline 487 & $5.21 \pm 3.2$ & NA & $13.4 \pm 5.67$ \\
\hline 491 & $11.12 \pm 4.37$ & $20 \pm 1.01$ & $9.31 \pm 3.98$ \\
\hline 519 & $85.12 \pm 4.76$ & $62.17 \pm 4.36$ & $84.71 \pm 2.86$ \\
\hline
\end{tabular}

TABLE 2: Determination of $\mathrm{IC}_{50}$ values for the extracts of strains 73,386 , and 519 cultivated in ISP 2; against prostate (PC3), lung (A549), and breast (MDA-MB-231) tumour lines. The results are expressed as an average \pm standard deviation $(n=3)$.

\begin{tabular}{|c|c|c|c|}
\hline \multicolumn{4}{|c|}{$\mathrm{IC}_{50}(\mathrm{ppm})$} \\
\hline Isolate & PC3 & A549 & MDA-MB-231 \\
\hline 73 & $64.84 \pm 3.85$ & $67.69 \pm 2.42$ & $43.24 \pm 1.96$ \\
\hline 386 & $6.14 \pm 2.07$ & $33.17 \pm 2.67$ & $70.72 \pm 4.87$ \\
\hline 519 & $64.58 \pm 4.76$ & $60.54 \pm 2.86$ & $45.89 \pm 2.36$ \\
\hline
\end{tabular}




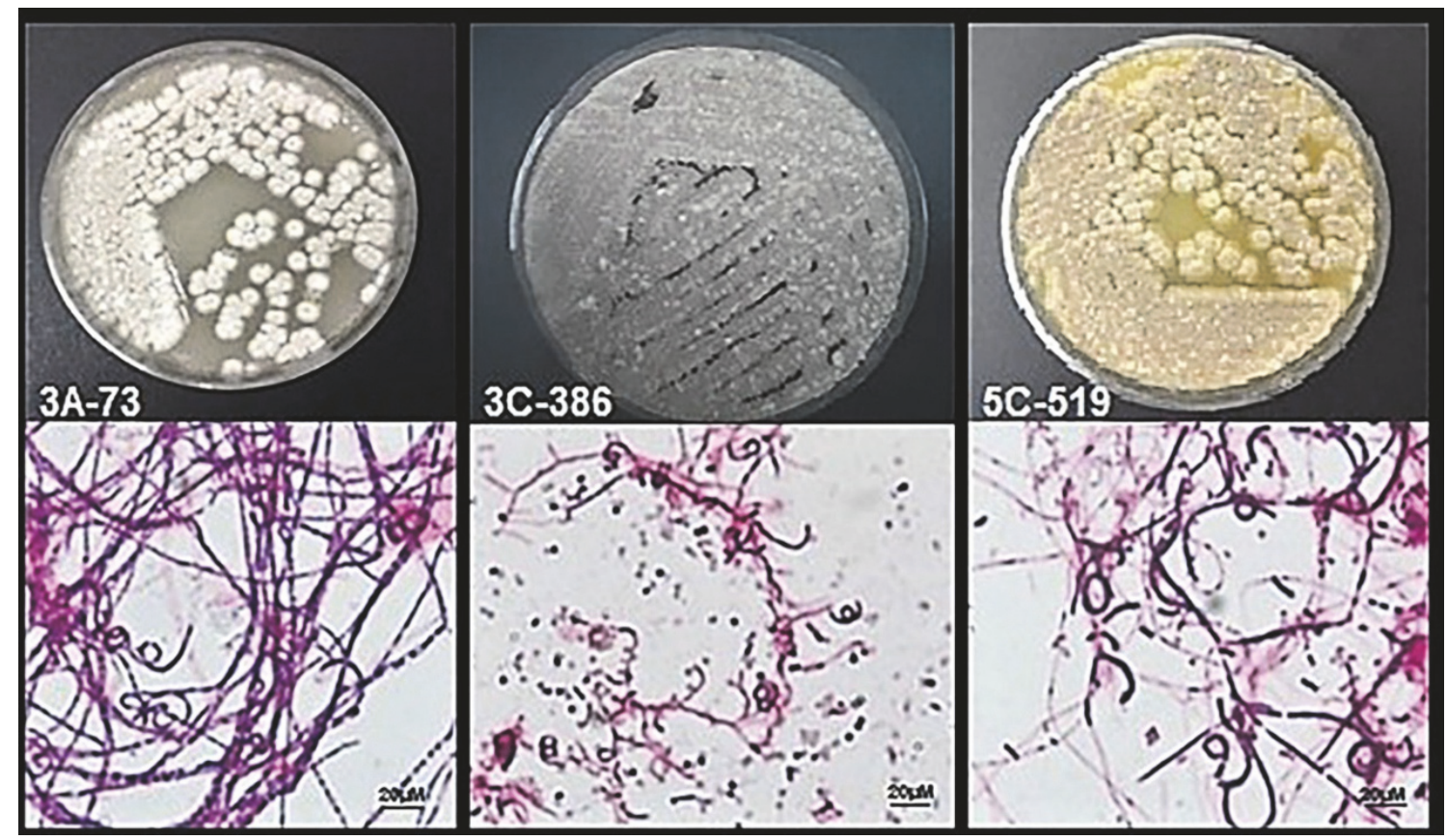

FIGURE 1: Morphologic features and Gram stain of Streptomyces strains with cytotoxic activity grown in ISP 3 agar medium.

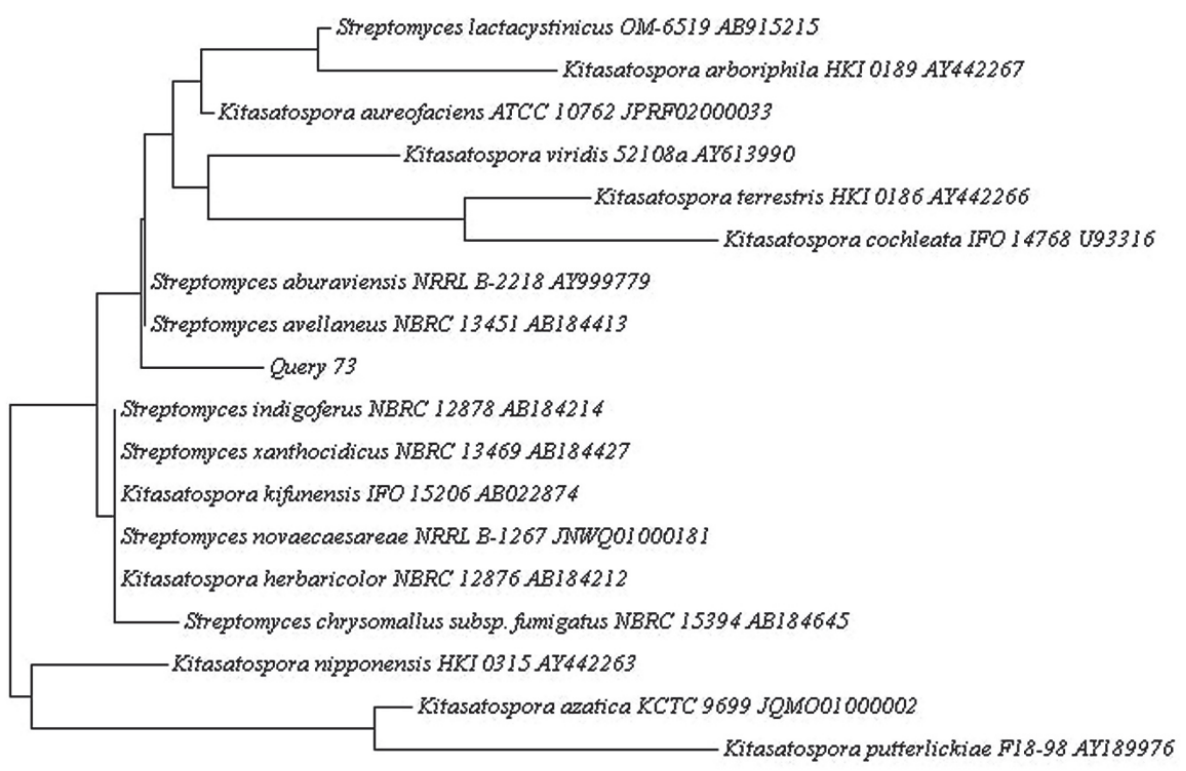

$\stackrel{0.001}{\longmapsto}$

FIGURE 2: Neighbor-Joining phylogenetic tree based on $16 \mathrm{~S}$ rRNA gene sequence showing the relationship between strain 73 and representatives of some other related taxa.

(519) had the best cytotoxic activity using malt extract as a nitrogen source with values of $49.13 \%, 59.73 \%$, and $77.59 \%$ for lung, breast, and prostate cancer, respectively, and had the lowest $\mathrm{IC}_{50}$ for the breast tumour cell line with a value of $41.23 \pm 2.84$ (Table 4 ).

3.3. Media Optimization Using Central Composite Design. After establishing the carbon and nitrogen sources, the effects of the concentration of nitrogen source (A), carbon source
(B), and $\mathrm{pH}(\mathrm{C})$ were studied using a central composite to determine the optimum level of these parameters leading to the maximum cytotoxic percent. The experimental design was tested carrying out 15 experiments for each isolate in the cell line that had the best cytotoxic effect; results are presented in Table 6.

One model was obtained from analysis of variance for each extract. F-test for the models showed statistical 


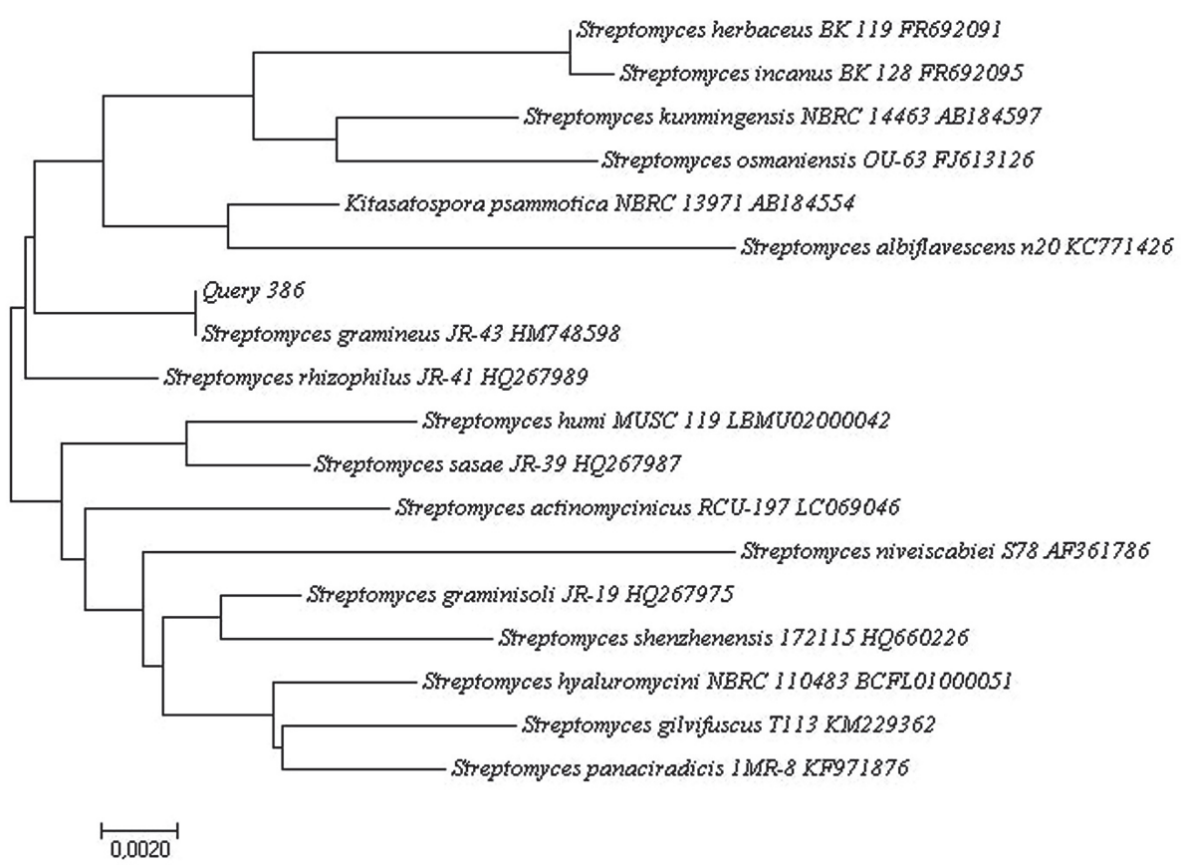

FIGURE 3: Neighbor-Joining phylogenetic tree based on $16 \mathrm{~S}$ rRNA gene sequence showing the relationship between strain 386 and representatives of some other related taxa.

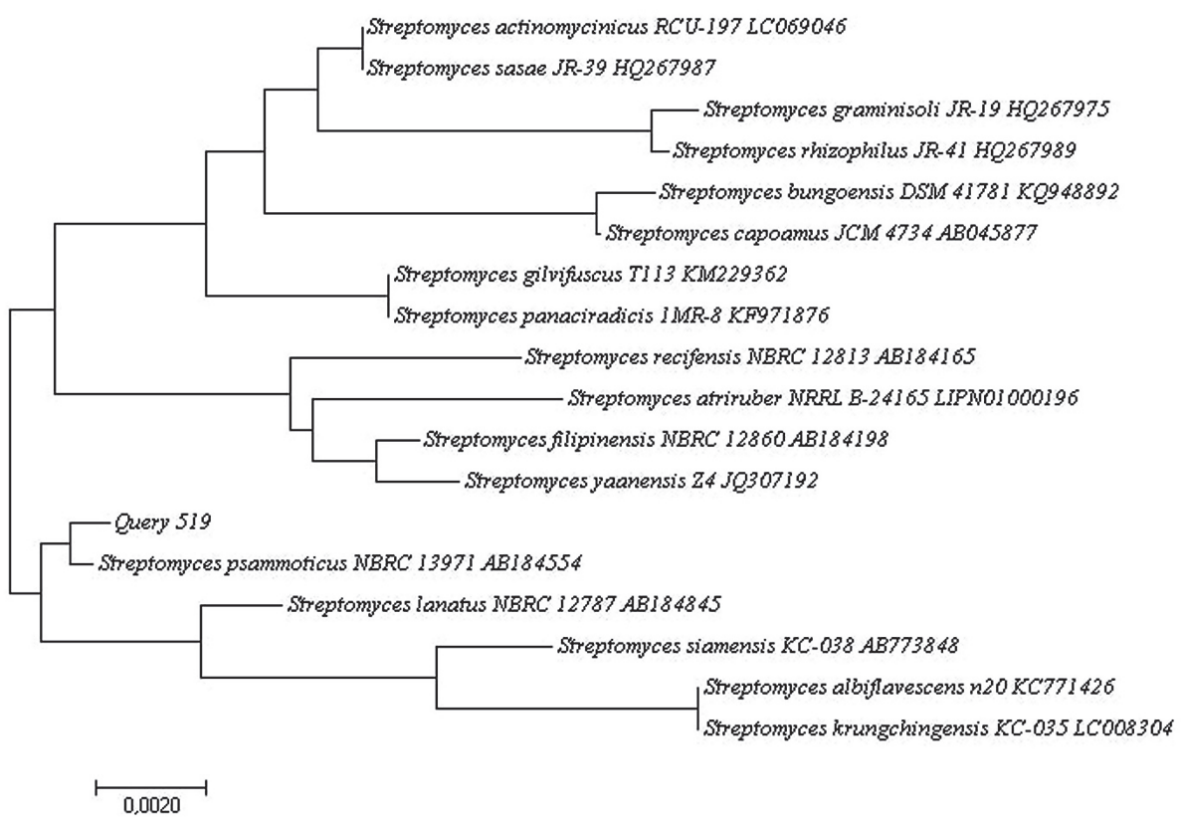

Figure 4: Neighbor-Joining phylogenetic tree based on $16 \mathrm{~S}$ rRNA gene sequence showing the relationship between strain 519 and representatives of some other related taxa.

significance $(\mathrm{P}<0,05)$, indicating that all models fit and can adequately explain the variations observed in the cytotoxic percent. Moreover, the lack of fit was not significant in all models at the $5 \%$ level $(\mathrm{P}<0.05)$, indicating that the experimental data obtained fit well with the model [21]. Coefficients of correlation $\mathrm{R}^{2}$ for the isolates Streptomyces aburaviensis (73), Streptomyces gramineus (386), and Streptomyces psammoticus (519) were $0.8089,0.8677$, and 0.8020 , respectively.

Table 7 shows the statistics analysis of cytotoxic activity from the isolate Streptomyces gramineus (386). As can be observed, the variables $\mathrm{A}, \mathrm{BC}$, and $\mathrm{C}^{2}$ were significant $(\mathrm{P}$ value $<0,05)$. The regression equation for the model in terms of cytotoxic percent $(\mathrm{Y})$ as a function of three independent 
TABLE 3: Determination of the carbon source that improved the cytotoxic percent at $100 \mathrm{ppm}$ of the Streptomyces extract for prostate (PC3), lung (A549), and breast (MDA-MB-231) tumour lines. The results are expressed as an average \pm standard deviation ( $\mathrm{n}=3$ ).

\begin{tabular}{|c|c|c|c|c|c|c|c|c|c|}
\hline \multicolumn{10}{|c|}{ \% Cytotoxicity at $100 \mathrm{ppm}$} \\
\hline & \multicolumn{3}{|c|}{73} & \multicolumn{3}{|c|}{386} & \multicolumn{3}{|c|}{519} \\
\hline & PC3 & A549 & MDA & PC3 & A549 & MDA & PC3 & A549 & MDA \\
\hline Saccharose & $90.07 \pm 0.21$ & $70.31 \pm 3.15$ & $65.96 \pm 3.06$ & $89.81 \pm 0.5$ & $75.11 \pm 0.74$ & $65.1 \pm 3.61$ & $88.71 \pm 0.82$ & $85.18 \pm 0.18$ & $59.18 \pm 0.84$ \\
\hline Glucose & $89.39 \pm 0.63$ & $78.17 \pm 2.54$ & $63.27 \pm 1.62$ & $90.64 \pm 0.56$ & $80.69 \pm 1.38$ & $57.11 \pm 2.03$ & $89.10 \pm 0.67$ & $86.78 \pm 2.86$ & $66.17 \pm 1.83$ \\
\hline Maltose & $89.05 \pm 1.05$ & $76.09 \pm 0.89$ & $57.86 \pm 2.74$ & $87.64 \pm 1.86$ & $72.28 \pm 1.24$ & $61.33 \pm 1.07$ & $89.70 \pm 0.48$ & $86.61 \pm 4.87$ & $59.27 \pm 0.72$ \\
\hline Xylose & $89.97 \pm 1.77$ & $81.83 \pm 4.76$ & $65.69 \pm 3.01$ & $89.60 \pm 0.57$ & $83.18 \pm 1.63$ & $65.63 \pm 2.32$ & $91.12 \pm 1.02$ & $87.78 \pm 1.26$ & $74.76 \pm 2.79$ \\
\hline Starch & $91.22 \pm 0.08$ & $83.90 \pm 1.05$ & $68.10 \pm 1.24$ & $88.93 \pm 1.02$ & $81.49 \pm 0.38$ & $64.35 \pm 0.84$ & $90.59 \pm 0.22$ & $87.79 \pm 0.58$ & $62.58 \pm 0.67$ \\
\hline
\end{tabular}

TABLE 4: Determination of the $\mathrm{IC}_{50}$ using the best carbon and nitrogen sources in Streptomyces strains for prostate (PC3), lung (A549), and breast (MDA-MB-231) tumour lines. The results are expressed as an average \pm standard deviation $(\mathrm{n}=3)$.

\begin{tabular}{|c|c|c|c|c|}
\hline \multicolumn{5}{|c|}{$\mathrm{IC}_{50}$} \\
\hline Isolate & PC3 & A549 & MDA-MB-231 & $\begin{array}{l}\text { Carbon source/ } \\
\text { Nitrogen source }\end{array}$ \\
\hline \multirow{2}{*}{73} & $50.26 \pm 2.54$ & $26.16 \pm 3.26$ & $26.65 \pm 0.86$ & Starch \\
\hline & $74.36 \pm 1.05$ & $69.13 \pm 1.05$ & $45.39 \pm 3.06$ & Yeast Extract \\
\hline \multirow{2}{*}{386} & $11.18 \pm 3.85$ & $31.64 \pm 1.45$ & $68.57 \pm 1.08$ & Xylose \\
\hline & $14.59 \pm 2.82$ & $16.35 \pm 4.03$ & $71.25 \pm 1.72$ & Malt Extract \\
\hline \multirow{2}{*}{519} & $55.80 \pm 2.96$ & $48.58 \pm 2.39$ & $39.98 \pm 3.27$ & Xylose \\
\hline & $68.43 \pm 2.74$ & $50.49 \pm 3.64$ & $41.23 \pm 2.84$ & Malt Extract \\
\hline
\end{tabular}

variables $(\mathrm{A}: \% \mathrm{w} / \mathrm{v}$ malt extract, $\mathrm{B}: \% \mathrm{w} / \mathrm{v}$ glucose, $\mathrm{C}: \mathrm{pH})$ is given below.

$$
\begin{aligned}
Y_{386}= & 5,861+36,996 \mathrm{~A}+2,260 \mathrm{~B}+12,823 \mathrm{C}-5,3 \mathrm{AC} \\
& -0,516 \mathrm{BC}-0,277 \mathrm{C}^{2}
\end{aligned}
$$

The response surface plot for the cytotoxic activity of Streptomyces gramineus (386) against lung cancer shows the interactive effect of different variables (\%w/v glucose, \%w/v malt extract, and $\mathrm{pH}$ ) presented in Figure 5(b). The highest theoretical value to maximize the cytotoxic percent to $100 \%$ was with $5 \%$ of malt extract, $3 \%$ of glucose, and a $\mathrm{pH}$ value of 6.

The regression equation for the cytotoxic activity from the Streptomyces aburaviensis (73) is shown in (3), where $\mathrm{Y}$ is the response in terms of cytotoxic percent, and the variables were \%w/v yeast extract (A), \%w/v starch (B), and $\mathrm{pH}(\mathrm{C})$. The significant terms ( $\mathrm{P}$ value $<0,05)$ for this model are $A$, $\mathrm{B}, \mathrm{C}, \mathrm{AB}, \mathrm{AC} \mathrm{y} \mathrm{B}^{2}$. In the response surface plot presented in Figure 5(a), it can be observed that the highest point to obtain $100 \%$ of cytotoxicity appeared at $4 \%$ of yeast extract, $3 \%$ of starch, and a $\mathrm{pH}$ value of 7 .

$$
\begin{aligned}
Y_{73}= & 95,859-22,383 \mathrm{~A}+0,546 \mathrm{~B}-3,566 \mathrm{C} \\
& +3.5660 \mathrm{AB}+2,671 \mathrm{AC}+0,260 \mathrm{~A}^{2}-1,194 B^{2}
\end{aligned}
$$

Finally, the model for the cytotoxic activity from the Streptomyces psammoticus (519) is given below as (4), showing the interactive effect between the variables $\% \mathrm{w} / \mathrm{v}$ malt extract (A), \%w/v xylose (B), and $\mathrm{pH}(\mathrm{C})$. The significant terms ( $\mathrm{P}$ value $<0,05)$ for this model were $B, C, B C y B^{2}$. The response surface plot presented in Figure 5(c) shows that the highest point for the isolate 519 against breast cancer is at $1 \%$ of yeast extract, $4 \%$ of starch, and a $\mathrm{pH}$ value of 8 .

$$
\begin{aligned}
Y_{519}= & 104,110-0,071 \mathrm{~A}-33,498 \mathrm{~B}-4,890 \mathrm{C} \\
& +5,784 \mathrm{BC}-1,316 \mathrm{~B}^{2}
\end{aligned}
$$

The best conditions of the tested variables obtained from the experimental design CCD had been verified experimentally (in triplicate) and compared with the predicted data (Table 8). The measured cytotoxic activity at $100 \mathrm{ppm}$ was $89.29 \% \pm 4.05$, $89.03 \% \pm 6.47$, and $66.18 \% \pm 2.83$ for Streptomyces aburaviensis (73), Streptomyces gramineus (386), and Streptomyces psammoticus (519), respectively. The predicted values from the model were $97.47 \%, 97.96 \%$, and $95.89 \%$. The verification revealed a high degree of accuracy of the model for Streptomyces aburaviensis (73) and Streptomyces gramineus (386), indicating the model's validation under the tested conditions. Moreover, the values of $\mathrm{IC}_{50}$ were measured at the best growth and nutritional conditions showing an increase compared with the initial results (Table 2). These assays were tested in L929 cell line without significative cytotoxic activity at low concentrations of extract (Figure 6).

3.4. Dry Biomass Growth Curve. The growth curves (Figure 7) obtained for this study were constructed from the average dry biomass obtained from three experiments after 10 days. The average of the dry biomass with standard error bars was plotted with the help of the statistical program GraphPad Prism $^{\circledR}$ version 6.01. The Gompertz model (Table 9) was used to describe the sigmoidal microbial growth curves 
TABLE 5: Determination of the nitrogen source that improved the cytotoxic percent at $100 \mathrm{ppm}$ of the Streptomyces extract for prostate (PC3), lung (A549), and breast (MDA-MB-231) tumour lines. The results are expressed as an average \pm standard deviation ( $\mathrm{n}=3$ ).

\begin{tabular}{lccccccccc}
\hline & \multicolumn{1}{c}{} & \multicolumn{9}{c}{ \% Cytotoxicity at 100 ppm } \\
& PC3 & A549 & MDA & PC3 & A549 & MDA & PC3 & A549 & MDA \\
\hline Yeast extract & $75.86 \pm 0.35$ & $63.45 \pm 0.65$ & $75.78 \pm 0.61$ & $69.32 \pm 0.28$ & $23.18 \pm 3.96$ & $18.07 \pm 2.70$ & $70.9 \pm 0.92$ & $37.86 \pm 0.79$ & $46.49 \pm 0.80$ \\
\hline Malt extract & $68.72 \pm 0.4$ & $22.50 \pm 0.59$ & $33.24 \pm 0.03$ & $86.76 \pm 4.76$ & $67.93 \pm 5.72$ & $54.46 \pm 0.36$ & $77.59 \pm 1.2$ & $49.13 \pm 2.55$ & $59.73 \pm 2.16$ \\
\hline Meat extract & $77.14 \pm 1.5$ & $33.69 \pm 5.58$ & $48.85 \pm 0.02$ & $72.93 \pm 0.98$ & $21.82 \pm 0.85$ & $29.77 \pm 1.54$ & $68.42 \pm 0.56$ & $40.91 \pm 2.96$ & $47.46 \pm 1.96$ \\
\hline Peptone & $71.12 \pm 5.32$ & $29.13 \pm 5.93$ & $37.59 \pm 0.94$ & $68.79 \pm 3.92$ & $28.56 \pm 5.51$ & $48.00 \pm 0.98$ & $64.92 \pm 4.98$ & $33.96 \pm 4.81$ & $33.96 \pm 2.83$ \\
\hline Potassium nitrate & $67.51 \pm 3.75$ & $16.07 \pm 4.15$ & $22.91 \pm 1.87$ & $66.39 \pm 1.81$ & $33.10 \pm 1.93$ & $37.28 \pm 1.79$ & $71.80 \pm 3.74$ & $31.18 \pm 3.62$ & $31.18 \pm 0.08$ \\
\hline
\end{tabular}

TABLE 6: Experimental design central composite design representing the cytotoxic percent by Streptomyces strains influenced by four variables and five levels of each on A: carbon source concentration, B: nitrogen source concentration, and C: $\mathrm{pH}$.

\begin{tabular}{|c|c|c|c|c|c|c|c|c|c|}
\hline \multirow{4}{*}{ Run } & \multirow{2}{*}{\multicolumn{3}{|c|}{ Independent variables }} & \multicolumn{6}{|c|}{ \% Cytotoxicity (100 ppm) } \\
\hline & & & & \multicolumn{3}{|c|}{ Observed value } & \multicolumn{3}{|c|}{ Predicted Value } \\
\hline & \multirow{2}{*}{$\begin{array}{c}\mathrm{A} \\
(\% \mathrm{w} / \mathrm{v})\end{array}$} & \multirow{2}{*}{$\begin{array}{c}\text { B } \\
(\% w / v)\end{array}$} & \multirow{2}{*}{$\mathrm{C}$} & 73 & 386 & 519 & 73 & 386 & 519 \\
\hline & & & & Against PC3 & $\begin{array}{c}\text { Against } \\
\text { A549 }\end{array}$ & $\begin{array}{c}\text { Against } \\
\text { MDA }\end{array}$ & Against PC3 & $\begin{array}{c}\text { Against } \\
\text { A549 }\end{array}$ & $\begin{array}{c}\text { Against } \\
\text { MDA }\end{array}$ \\
\hline 1 & 2.5 & 2 & 6 & 78.05 & 83.482 & 73.204 & 77.319 & 84.139 & 71.740 \\
\hline 2 & 2.5 & 0.4 & 8 & 75.075 & 74.138 & 72.774 & 73.985 & 76.455 & 69.707 \\
\hline 3 & 0.5 & 2 & 8 & 71.182 & 82.695 & 87.936 & 70.728 & 84.274 & 85.239 \\
\hline 4 & 0.5 & 0.4 & 6 & 75.075 & 75.54 & 74.374 & 75.060 & 75.090 & 75.003 \\
\hline 5 & 0.1 & 0.8 & 7 & 74.44 & 81.127 & 72.715 & 73.952 & 80.956 & 74.620 \\
\hline 6 & 5 & 0.8 & 7 & 76.138 & 81.127 & 72.715 & 76.401 & 80.439 & 74.271 \\
\hline 7 & 1.4 & 0.1 & 7 & 70.717 & 81.705 & 72.834 & 70.258 & 81.766 & 70.462 \\
\hline 8 & 1.4 & 4 & 7 & 72.547 & 77.078 & 75.952 & 72.753 & 76.486 & 76.688 \\
\hline 9 & 1.4 & 0.8 & 5 & 72.547 & 77.078 & 75.952 & 72.044 & 77.487 & 75.054 \\
\hline 10 & 1.4 & 0.8 & 9 & 74.824 & 83.369 & 72.434 & 74.720 & 81.934 & 74.001 \\
\hline 11 & 1.4 & 0.8 & 7 & 73.085 & 80.37 & 73.929 & 73.382 & 80.819 & 74.528 \\
\hline 12 & 1.4 & 0.8 & 7 & 70.717 & 80.078 & 72.709 & 73.382 & 80.819 & 74.528 \\
\hline 13 & 1.4 & 0.8 & 7 & 72.767 & 81.494 & 74.946 & 73.382 & 80.819 & 74.528 \\
\hline 14 & 1.4 & 0.8 & 7 & 72.767 & 81.568 & 72.918 & 73.382 & 80.819 & 74.528 \\
\hline 15 & 1.4 & 0.8 & 7 & 74.198 & 82.272 & 74.033 & 73.382 & 80.819 & 74.528 \\
\hline
\end{tabular}

TABLE 7: Analysis of variance for the fit second order polynomial model and lack of fit for the cytotoxic percent by composite central design for the strain Streptomyces gramineus (386). SS: sum of squares, DF: degrees of freedom, MSS: mean sum of squares.

\begin{tabular}{|c|c|c|c|c|c|}
\hline Source & Sum of squares & DF & Mean square & F value & p-value \\
\hline Model & 101.406 & 6 & 16.901 & 8.746 & 0.0037 \\
\hline A & 0.162 & 1 & 0.162 & 0.084 & 0.7790 \\
\hline $\mathrm{B}$ & 18.572 & 1 & 18.572 & 9.611 & 0.0147 \\
\hline $\mathrm{C}$ & 32.920 & 1 & 32.920 & 17.037 & 0.0033 \\
\hline $\mathrm{AC}$ & 90.358 & 1 & 90.358 & 46.762 & 0.0001 \\
\hline $\mathrm{BC}$ & 0.644 & 1 & 0.644 & 0.333 & 0.5795 \\
\hline $\mathrm{C} \wedge 2$ & 1.987 & 1 & 1.987 & 1.028 & 0.3402 \\
\hline Residual & 15.458 & 8 & 1.932 & & \\
\hline Lack of Fit & 12.147 & 4 & 3.037 & 3.669 & 0.1180 \\
\hline Pure Error & 3.310 & 4 & 0.827 & & \\
\hline Cor Total & 116.865 & 14 & & & \\
\hline
\end{tabular}


TABLE 8: Verification of the accuracy of the models obtained with CCP and de $\mathrm{IC}_{50}$ at the best environmental and growth conditions. Experimental results are expressed as an average \pm standard deviation $(n=3)$.

\begin{tabular}{lccccc}
\hline Isolate & $\begin{array}{c}\text { \%Cytotoxicity } \\
\text { at } \mathbf{1 0 0} \mathbf{~ p p m}\end{array}$ & Predicted & \%Error & IC $_{\mathbf{5 0}}(\mathbf{p p m})$ & Cell line \\
\hline $\mathbf{7 3}$ & $89.29 \% \pm 4.05$ & 97.47 & $8.40 \%$ & $25.00 \pm 1.86$ & A549 \\
\hline $\mathbf{3 8 6}$ & $89.03 \% \pm 6.47$ & 95.45 & $6.73 \%$ & $7.93 \pm 0.98$ & \\
\hline $\mathbf{5 1 9}$ & $66.18 \% \pm 2.83$ & 94.96 & $30.31 \%$ & $35.53 \pm 2.71$ & PC3 \\
\hline
\end{tabular}

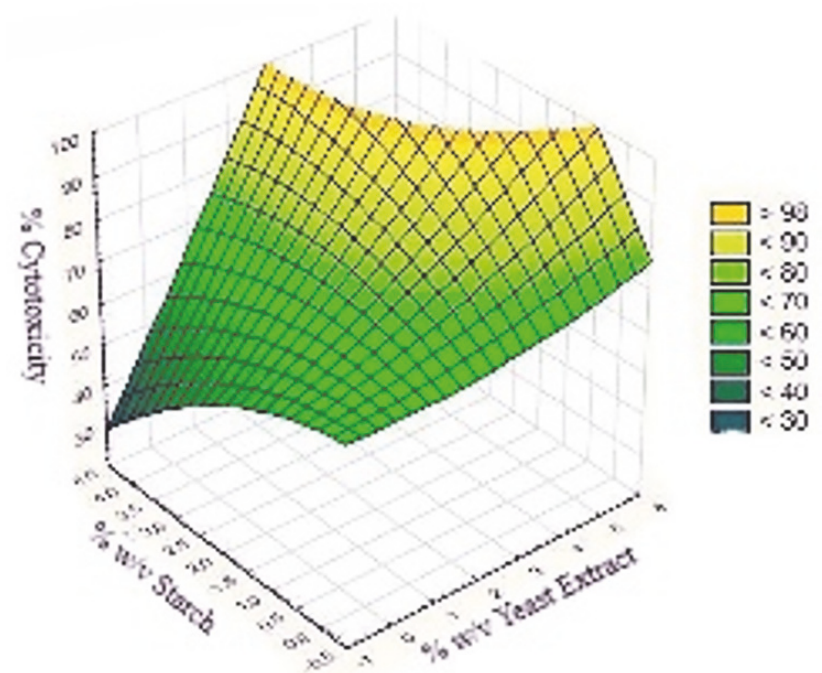

(a)

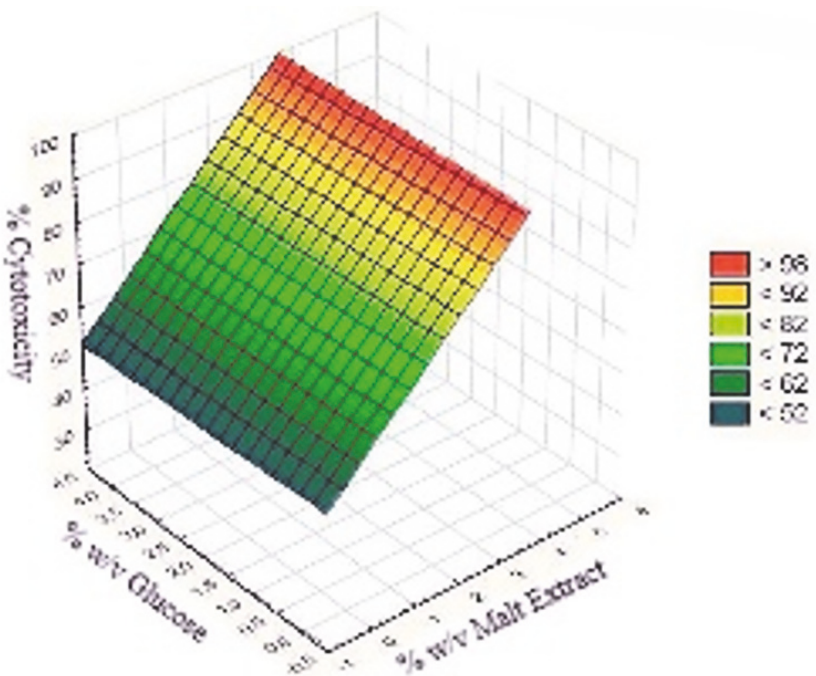

(b)

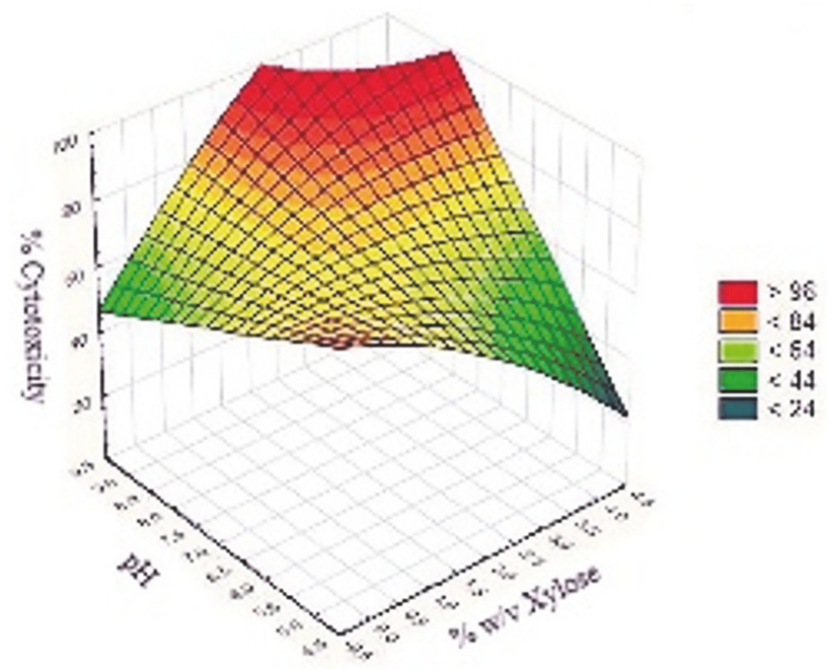

(c)

FIGURE 5: Surface plots for interactions between nitrogen source concentration and carbon source concentration at the best $\mathrm{pH}$ predicted for (a) Streptomyces aburaviensis (73) pH 6 and (b) Streptomyces gramineus (386) pH 7. The surface plot for (c) Streptomyces psammoticus (519) represents the interaction between carbon source concentration and $\mathrm{pH}$ with best nitrogen source concentration $(1 \% \mathrm{w} / \mathrm{v}) \mathrm{predicted}$.

shown in Figure 7; all models exhibit a high correlations $\left(\mathrm{R}^{2}\right)$ with values of 0.99 for Streptomyces aburaviensis (73), 0.98 for Streptomyces gramineus (386), and 0.98 for Streptomyces psammoticus (519).

3.5. LC-MS Analysis. The chromatograms obtained for the extracts tested showed defined signal patterns characteristic of each type of extract as indicated by arrows (Figure 8). Organic extracts showed the majority of signals between 11 and $28 \mathrm{~min}$ retention time (RT) and signals with mass/charge $(\mathrm{m} / \mathrm{z})$ relationship values from 160 to 820 . The extract of Streptomyces gramineus (386) differs from the extracts of Streptomyces aburaviensis (73) and Streptomyces psammoticus (519) in the signals corresponding to retention time of 


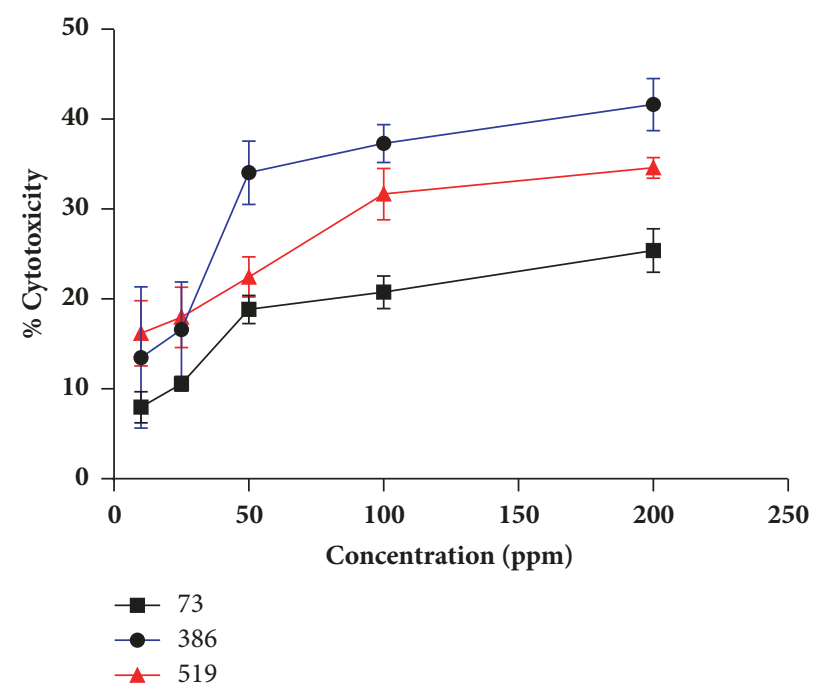

FIGURE 6: Cytotoxic activity tested in L929 cell line for Streptomyces aburaviensis (73), Streptomyces gramineus (386), and Streptomyces psammoticus (519). Standard deviation $(\mathrm{n}=3)$.

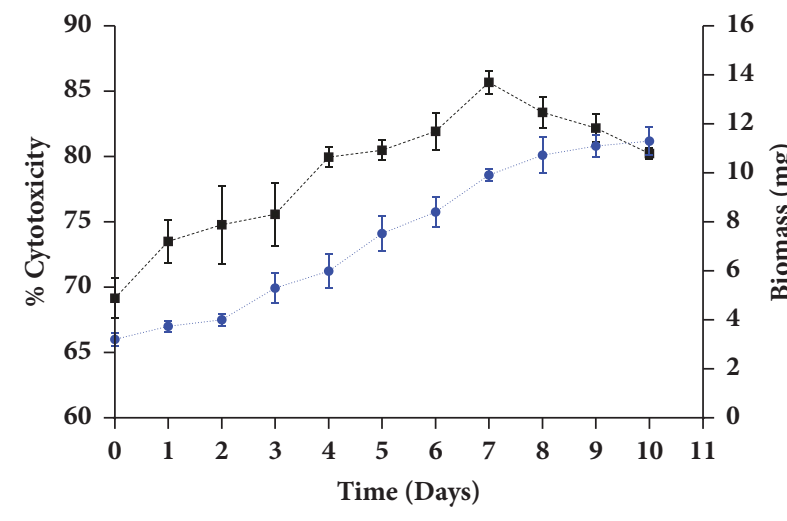

-... Biomass

-... \% Cytotoxicity

(a)

(a)

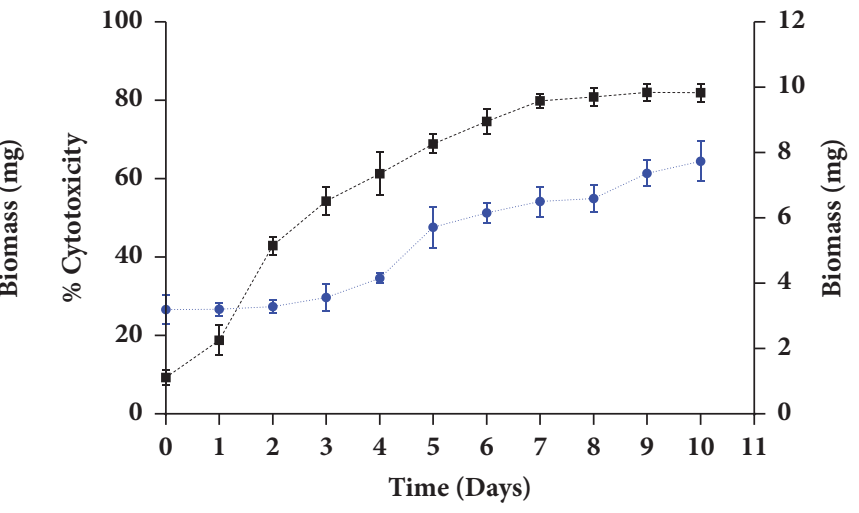

- Biomass

...... \% Cytotoxicity

(b)

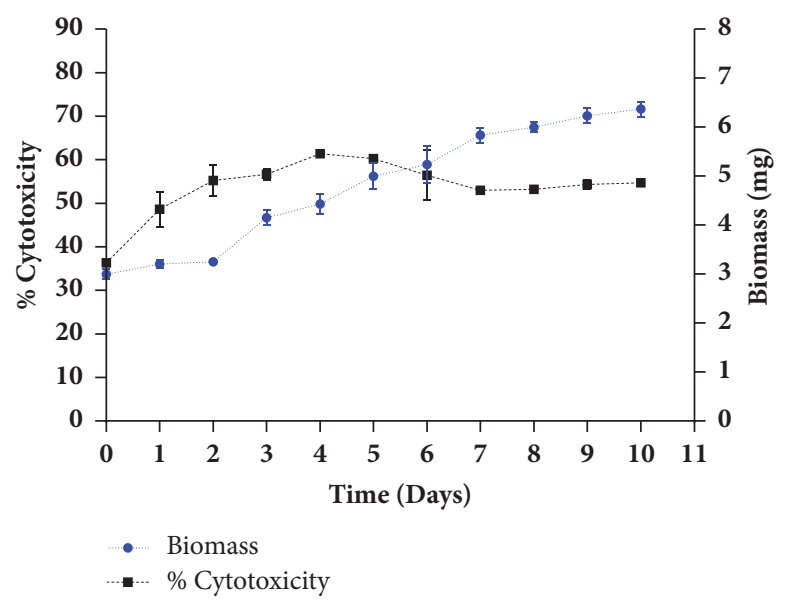

(c)

Figure 7: Growth kinetics of Streptomyces aburaviensis (73) against lung tumour cell line (a), Streptomyces gramineus (386) against prostate tumour cell line (b), and Streptomyces psammoticus (519) against breast tumour cell line (c) and dependent variables growth (mg; (blue filled circles)) and \%cytotoxicity (\%; (black filled squares)). Standard deviation $(\mathrm{n}=3)$. 


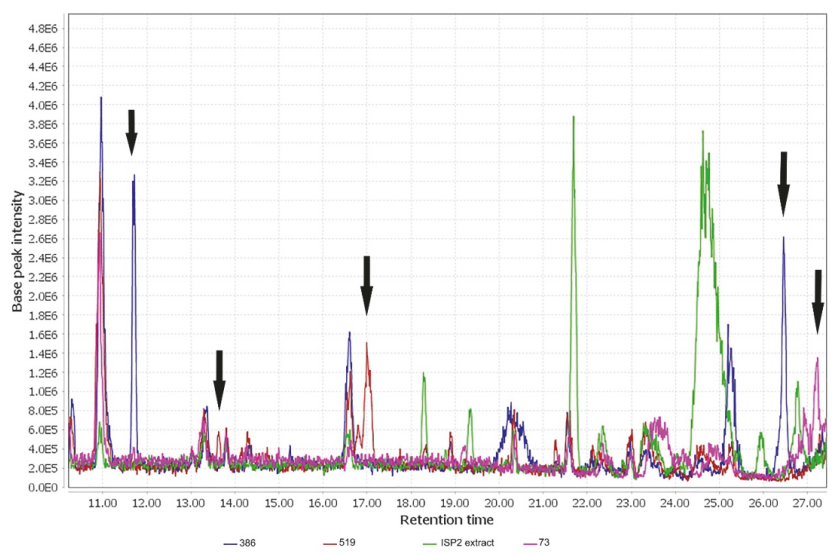

Figure 8: Liquid Chromatography comparison spectrum for organic extracts from Streptomyces gramineus (386), Streptomyces aburaviensis (73), and Streptomyces psammoticus (519) and control extract from ISP 2 media without biomass (the arrows indicate the peaks that differ from the other extracts).

TABLE 9: Results of Gompertz model growth rate ( $\mu$ Max), the lag time $(\lambda)$, and the coefficients of correlation $\left(\mathrm{R}^{2}\right)$.

\begin{tabular}{lccc}
\hline Isolate & $\boldsymbol{\mu}_{\mathbf{M a x}(\text { day }}$ & $\lambda$ (day) & $\mathbf{R}^{\mathbf{2}}$ \\
\hline $\mathbf{7 3}$ & 1.18 & 1.71 & 0.99 \\
\hline $\mathbf{3 8 6}$ & 0.98 & 2.64 & 0.95 \\
\hline $\mathbf{5 1 9}$ & 0.50 & 1.26 & 0.98 \\
\hline
\end{tabular}

$11.67 \mathrm{~min}, \mathrm{~m} / \mathrm{z}=408.6$ and $26.44 \mathrm{~min}, \mathrm{~m} / \mathrm{z}=709.4$. The strain Streptomyces psammoticus (519) presented characteristic signals at $13.62 \mathrm{~min}, \mathrm{~m} / \mathrm{z}=207.25$ and $17.01 \mathrm{~min}, \mathrm{~m} / \mathrm{z}=453.2$ and Streptomyces aburaviensis (73) at $27.25 \mathrm{~min}, \mathrm{~m} / \mathrm{z}=817.7$.

\section{Discussion}

Cancer is the second leading cause of death in the world behind cardiovascular disease [5]. Despite this, chemotherapy is still one of the most used cancer treatments even with its range of serious side effects. To decrease the side effects of chemotherapy, new biologically active metabolites are needed to be explored, and natural product extracts continue to be the most promising source of new drugs for cancer [14]. Through this research, we found three Streptomyces strains isolated from Guaviare river sediments (Colombia, South America) with cytotoxic activity against prostate, lung, and breast cancer cell lines. The isolates were identified morphologically and molecularly as Streptomyces aburaviensis (73), Streptomyces gramineus (386), and Streptomyces psammoticus (519). Some studies describe Streptomyces aburaviensis (73) [35, 36] and Streptomyces psammoticus (519) [37, 38] with antibacterial and antifungal activity. In fact only Streptomyces gramineus (386) has been reported with cytotoxic activity; two compounds have been isolated from this strain with a moderate cytotoxic activity against SKOV-3 (ovarian cancer cell line), Meso-1 (human malignant mesothelioma cell line), and Jurkat (leukemia cell line) cells with $\mathrm{IC}_{50}$ values of 2.3, 2.5, and $1.0 \mu \mathrm{M}[39]$.

Three organic extracts were obtained from strains Streptomyces aburaviensis (73), Streptomyces gramineus (386), and
Streptomyces psammoticus (519), which presented cytotoxic activity against lung, prostate, and breast cancer, respectively (Table 2). Furthermore, the organic extracts showed chemical differences analysed in LC-MS chromatogram (Figure 8). Streptomyces gramineus (386) spectrum showed a signal related to the compound diacarnoxide-A $(\mathrm{RT}=11.67, \mathrm{~m} / \mathrm{z}=$ 408.6), which has been reported with cytotoxic activity against prostate cancer (PC3) and breast cancer (MDAMB231) by Jingqiu et al. [40]. LC-MS analysis showed the possible presence of Streptophenazine I $(\mathrm{RT}=17.01 ; \mathrm{m} / \mathrm{z}=453.2$ $\left.(\mathrm{M}+\mathrm{H})^{+}\right)$in the organic extract of Streptomyces psammoticus (519), which has been reported by Bunbamrung et al. with cytotoxic activity against breast (MCF-7) and lung cancer (NCI-H187) [41].

In order to optimize the cytotoxic activity of the three Streptomyces strains, five carbon sources were evaluated. Several reports take into consideration the role of the carbon source to enhance the biological activity, therefore Streptomyces aburaviensis (73) improved 2.58 times the cytotoxic activity against the lung tumour cell line using starch instead of glucose as a carbon source. Thumar et al. [42] demonstrated that the use of starch as a carbon source in Streptomyces aburaviensis (73) enhances growth and antibiotic production. Moreover, Streptomyces gramineus (386) had the best cytotoxic activity against the prostate cancer cell line using glucose as a carbon source instead of xylose because glucose demonstrated a higher cytotoxic activity at lower concentrations of extract. Similarly, Lee et al. [32] reported that glucose favours the growth of this strain as in this investigation. Streptomyces psammoticus (519) had the higher cytotoxic activity using xylose as a carbon source as Hamed et al. [43] reported that this strain is able to metabolize xylose to grow in culture, and Sujatha et al. [44] reported antibiotic production using this carbon source.

Subsequently, the nitrogen sources that increased the cytotoxic activity for Streptomyces strains were malt extract and yeast extract, which means that the cytotoxic activity is related to the synergic interaction between these nitrogen sources. It is why the cytotoxic screen was made using ISP 2 and the production of the cytotoxic compounds must be 
stimulated for these nitrogen sources. Likewise, some studies confirm that the nature of the nitrogen sources strongly affects bioactive compounds production [17] in different organisms. Raytapadar and Paul [45] found that the yeast extract supports the growth in Streptomyces aburaviensis (73). Similarly, the antibiotic [43] and laccase [46] production was enhanced using yeast extract as a nitrogen source in Streptomyces psammoticus (519), and the cytotoxic production was increased by yeast extract in Streptomyces sp. VITPSA [47].

The cytotoxic activity of the three Streptomyces strains was affected by different environmental and nutritional growth conditions (Figure 5). Firstly, the $\mathrm{pH}$ was the most influential variable in all models, the range 7-9 of $\mathrm{pH}$ constitutes the optimal values for Streptomyces aburaviensis (73) and Streptomyces psammoticus (519). Researchers confirm that Streptomyces aburaviensis (73) grow well at $\mathrm{pH}$ of 9 [42] and enhance its antibiotic production at 7.4 [45]. Moreover, Streptomyces psammoticus (519) increases the production of extracellular bioactive metabolites in a $\mathrm{pH}$ of 6.5 [43]. At last Streptomyces gramineus (386) has an optimal $\mathrm{pH}$ value of 6 , and some studies report that this strain grows well at $\mathrm{pH}$ 4-8 [45]. Similarly, the interaction between starch with $\mathrm{pH}$ and yeast was significant to increase the cytotoxic activity of Streptomyces aburaviensis (73). The most important conditions besides $\mathrm{pH}$ for Streptomyces gramineus (386) and Streptomyces psammoticus (519) were the nitrogen and carbon sources, respectively.

Balachandran et al. [15] showed the relationship between cytotoxic activity and cell growth; this behaviour was observed in the present investigation for Streptomyces aburaviensis $(73)$, which had a growth rate $\left(\mu_{\mathrm{Max}}\right)$ of $1.18 \mathrm{day}^{-1}$ (Table 9 ) and had the maximum cytotoxic activity on the seventh day according to the inflection point of the growth curve (Figure 7(a)). Also, some studies of Streptomyces aburaviensis have reported that this strain secreted antibiotic in the culture after seven days of fermentation [45]. The strain Streptomyces gramineus (386) also had the highest cytotoxic activity in the seventh day, and it kept stable until the tenth day with a growth rate $\left(\mu_{\mathrm{Max}}\right)$ of $0.98 \mathrm{day}^{-1}$ (Table 9$)$. In addition, the strain Streptomyces psammoticus (519) had a growth rate $\left(\mu_{\mathrm{Max}}\right)$ of $0.50^{\text {day-1 }}$ (Table 9) and presented the cytotoxic activity in the exponential phase. The cytotoxic activity (Figure 7(c)) of Streptomyces psammoticus (519) decreases when the stationary phase begins (fifth day); this behaviour is similar in comparison with Hamed-Mohamedin et al., who set the fermentation day until the fifth day for the production of bioactive metabolites using Streptomyces psammoticus [43].

Consequently, Streptomyces aburaviensis (73) and Streptomyces gramineus (386) at the best nutritional and growth conditions showed a high cytotoxic activity, and Streptomyces psammoticus (519) had a moderate cytotoxic activity. Despite this, the National Cancer Institute of United States estimated that the value of $\mathrm{IC}_{50}$ has to be lower than $30 \mathrm{ppm}$ to have a high cytotoxic activity for a crude extract [48]. Hence, the value of $\mathrm{IC}_{50}$ for Streptomyces aburaviensis (73) against lung cancer (A549) was 25.00 $\pm 1.86 \mathrm{ppm}$, which was much greater than other Actinobacteria's cytotoxic activities. For instance, Nocardia dassonvillei produced a novel anticancer phenazine that had a $\mathrm{IC}_{50}$ of 38.53 ppm against A549 [49]. Also, the Actinobacterial strains ERIA-31 and ERIA-33 produced a protease enzyme that was tested in A549 cell line and presented $\mathrm{IC}_{50}$ values of $57.04 \mathrm{ppm}$ and $55.07 \mathrm{ppm}$, respectively [50].

Streptomyces psammoticus (519) had a $\mathrm{IC}_{50}$ value of $35.53 \pm 2.7$ ppm against breast cancer (MDA-MB-231). Similarly, Actinobacterial strains ACT01, ACT02, and ACT03 showed $\mathrm{IC}_{50}$ values of $32.79 \pm 6.94,69.84 \pm 19.54$, and $84.09 \pm 18.93 \mathrm{ppm}$ against MDA-MB-231 [16]. However, recently Actinobacterial strains EGY2 and EGY39 showed a high cytotoxic activity for the crude extracts with $\mathrm{IC}_{50}$ values of $19.50 \pm 0.03 \mathrm{ppm}$ and $29.6 \pm 0.43 \mathrm{mg} / \mathrm{mL}$, respectively [53] Finally, the strain Streptomyces gramineus (386) showed the highest $\mathrm{IC}_{50}$ value among all three Streptomyces strains studied in this investigation, with a value of $7.93 \pm 0.98 \mathrm{ppm}$ against prostate cancer (PC3) with the growth and environmental conditions of the experimental design, but it does not have a significant difference with the first value of $6.14 \pm 2.07 \mathrm{ppm}$ (Table 2).

The results indicate that Streptomyces aburaviensis (73), Streptomyces gramineus (386), and Streptomyces psammoticus (519) showed a promising cytotoxic activity against lung, prostate, and breast cancer, respectively. Furthermore, the extracts did not show a significative toxic activity against L929 (mouse fibroblasts) at values lower than $50 \mathrm{ppm}$ of extract (Figure 6). The optimizing nutritional and growing factors improve the cytotoxic activity of Streptomyces aburaviensis (73) in $61.35 \%$ against lung cancer and $22.57 \%$ for Streptomyces psammoticus (519) against breast cancer.

\section{Conclusions}

The study revealed that the optimization of the environmental and nutritional conditions in growth culture improves the cytotoxic activity of extracts from Streptomyces aburaviensis (73) and Streptomyces psammoticus (519). However, Streptomyces gramineus (386) had a high cytotoxic activity (less than $30 \mathrm{ppm}$ ) with the initial conditions because the medium propitiated the stimulation of the cytotoxic activity without being able to improve it more.

This study reveals that the strategy of optimizing the environmental and nutritional conditions in growth culture had a positive impact in the cytotoxic activity, leading the investigation group to a new strategy. Also, the incorporation of techniques like HPLC-MS and MR will be used to identify the compounds responsible for the cytotoxic activity. In future studies, flow cytometry and Western blot will be carried out to identify the cellular and biochemical mechanisms that lead to the cytotoxic activity of extracts.

\section{Data Availability}

The data used to support the findings of this study are available from the corresponding author upon request.

\section{Conflicts of Interest}

The authors have no conflicts of interest to declare. 


\section{Acknowledgments}

The research and publication of this article was funded by Universidad de La Sabana, Grant no. [ING-137-2013]. The authors are grateful to the members of the group ProNIUS, Universidad de La Sabana, for substantially supporting the research with all the equipment, reagents, and facilities and for the helpful comments and encouraging remarks. The authors are thankful to Professor Ericsson Coy Barrera of Nueva Granada Military University for the support in the LCMS analysis.

\section{References}

[1] A. Ilbawi, C. Varghese, B. Loring, O. Ginsburg, and M. Corbex, "Guide to Cancer Early Diagnosis," World Health Organization, pp. 1-38, 2017.

[2] R. L. Siegel, K. D. Miller, and A. Jemal, "Cancer statistics, 2018," CA: A Cancer Journal for Clinicians, vol. 68, no. 1, pp. 7-30, 2018.

[3] R. L. Siegel, K. D. Miller, and A. Jemal, "Cancer statistics, 2017," CA: A Cancer Journal for Clinicians, vol. 67, no. 1, pp. 7-30, 2017.

[4] R. Siegel, K. Miller, and A. Jemal, "Cancer facts and figures for hispanics/latinos 2015-2017," American Cancer Society, pp. 1-42, 2017.

[5] A. L. Demain and P. Vaishnav, "Natural products for cancer chemotherapy," Microbial Biotechnology, vol. 4, no. 6, pp. 687699, 2011.

[6] A. Gomathi and K. M. Gothandam, "Ocean Dwelling Actinobacteria as Source of Antitumor Compounds," Brazilian Archives of Biology and Technology, vol. 59, pp. 1-21, 2016.

[7] S. Navami, M. Lekshmi, and A. Jayadev, "Isolation and partial characterization of marine actinomycetes," International Journal of Advanced Research, vol. 3, no. 11, pp. 695-706, 2015.

[8] N. Pastrana-Camacho, Z. Suárez, A. Acosta-González et al., "Bioprospecting for culturable actinobacteria with antimicrobial properties isolated from rivers in Colombian Orinoquia," Tropical Journal of Pharmaceutical Research, vol. 15, no. 6, pp. 1259-1265, 2016.

[9] A. Ayuso, D. Clark, I. González, O. Salazar, A. Anderson, and O. Genilloud, "A novel actinomycete strain de-replication approach based on the diversity of polyketide synthase and nonribosomal peptide synthetase biosynthetic pathways," Applied Microbiology and Biotechnology, vol. 67, no. 6, pp. 795-806, 2005.

[10] H. B. Bode, B. Bethe, R. Höfs, and A. Zeeck, "Big effects from small changes: Possible ways to explore nature's chemical diversity," ChemBioChem, vol. 3, no. 7, pp. 619-627, 2002.

[11] W. Whitman, M. Goodfellow, P. Kämpfer, and P. Kämpfer, "Bergey's manual of systematic bacteriology", in The Actinobacteria, vol. 5, Springer Science \& Business Media, Athens, Georgia, 2nd edition, 2012.

[12] E. B. Shirling and D. Gottileb, "Methods for characterization of Streptomyces species," Internattional Juornal of Systematic Bacteriology, vol. 16, no. 3, pp. 313-340, 1966.

[13] V. Mendhulkar and K. Sopan, "Isolation, characterization and screening for anticancer property of sediment derived actinomycetes from south east coast of india," International Journal of Pharma and Bio Sciences, vol. 6, no. 2, pp. 36-52, 2015.

[14] H.-L. Ser, N.-S. A. Mutalib, W.-F. Yin, K.-G. Chan, B.-H. Goh, and L.-H. Lee, "Evaluation of antioxidative and cytotoxic activities of Streptomyces pluripotens MUSC 137 isolated from mangrove soil in Malaysia," Frontiers in Microbiology, vol. 6, no. DEC, Article ID 01398, pp. 1-11, 2015.

[15] C. Balachandran, B. Sangeetha, V. Duraipandiyan et al., "A flavonoid isolated from Streptomyces sp. (ERINLG-4) induces apoptosis in human lung cancer A549 cells through p53 and cytochrome c release caspase dependant pathway," ChemicoBiological Interactions, vol. 224, pp. 24-35, 2014.

[16] S. Ravikumar, M. Fredimoses, and M. Gnanadesigan, "Anticancer property of sediment actinomycetes against MCF-7 and MDA-MB-231 cell lines," Asian Pacific Journal of Tropical Biomedicine, vol. 2, no. 2, pp. 92-96, 2012.

[17] C. Balachandran, V. Duraipandiyan, Y. Arun et al., "Isolation and characterization of 2-hydroxy-9,10-anthraquinone from Streptomyces olivochromogenes (ERINLG-261) with antimicrobial and antiproliferative properties," Revista Brasileira de Farmacognosia, vol. 26, no. 3, pp. 1-11, 2016.

[18] S. Jemimah Naine, C. Subathra Devi, V. Mohanasrinivasan, and B. Vaishnavi, "Antimicrobial, antioxidant and cytotoxic activity of marine Streptomyces parvulus VITJS11 crude extract," Brazilian Archives of Biology and Technology, vol. 58, no. 2, pp. 198-207, 2015.

[19] P. Chand, C. K. Naveen, P. Murthy, and M. Isaac, "Evaluation of bioactive compounds produced by Nocardia levis MK-VL_113 \& Streptomyces tendae TK-VL_333 for cytotoxic activity," Indian Journal of Medical Research, vol. 137, no. 2, pp. 391-393, 2013.

[20] D. Madhusudhan, B. Z. Mazhari, S. G. Dastager, and D. Agsar, "Production and cytotoxicity of extracellular insoluble and droplets of soluble melanin by Streptomyces lusitanus DMZ-3," BioMed Research International, vol. 2014, pp. 100-111, 2017.

[21] V. Karuppiah, C. Aarthi, K. Sivakumar, and L. Kannan, "Statistical optimization and anticancer activity of a red pigment isolated from Streptomyces sp. PM4," Asian Pacific Journal of Tropical Biomedicine, vol. 3, no. 8, pp. 650-656, 2013.

[22] N. E. El-Naggar, H. Moawad, N. M. El-Shweihy, and S. M. El-Ewasy, "Optimization of culture conditions for production of the anti-leukemic glutaminase free l-asparaginase by newly isolated streptomyces olivaceus NEAE-119 using response surface methodology," BioMed Research International, vol. 2015, p. 627031, 2015.

[23] N. A. Magarvey, J. M. Keller, V. Bernan, M. Dworkin, and D. H. Sherman, "Isolation and characterization of novel marinederived actinomycete taxa rich in bioactive metabolites," Applied and Environmental Microbiology, vol. 70, no. 12, pp. 7520-7529, 2004.

[24] P. Yarza, M. Richter, J. Peplies et al., “The All-Species Living Tree project: A $16 \mathrm{~S}$ rRNA-based phylogenetic tree of all sequenced type strains," Systematic and Applied Microbiology, vol. 31, no. 4, pp. 241-250, 2008.

[25] F. A. Bernal, L. L. Orduz-Díaz, and E. Coy-Barrera, "Application of PARAFAC and OPLS-DA analyses on HPLC fingerprints for the characterization of Hibiscus sabdariffa calyxes," Química Nova, vol. 39, no. 2, pp. 160-166, 2016.

[26] T. V. K. Reddy, S. Mahmood, L. Paris, Y. H. K. Reddy, E. M. H. Wellington, and M. M. Idris, "Streptomyces hyderabadensis sp. nov., an actinomycete isolated from soil," International Journal of Systematic and Evolutionary Microbiology, vol. 61, no. 1, pp. 76-80, 2011.

[27] J. D. Thompson, T. J. Gibson, F. Plewniak, F. Jeanmougin, and D. G. Higgins, "The CLUSTAL X windows interface: flexible strategies for multiple sequence alignment aided by quality analysis tools," Nucleic Acids Research, vol. 25, no. 24, pp. 48764882, 1997. 
[28] N. Saitou and M. Nei, "The neighbor-joining method: a new method for reconstructing phylogenetic trees," Molecular Biology and Evolution, vol. 4, no. 4, pp. 406-425, 1987.

[29] S. Kumar, G. Stecher, and K. Tamura, "MEGA7: Molecular Evolutionary Genetics Analysis version 7.0 for bigger datasets," Molecular Biology and Evolution, vol. 33, no. 7, pp. 1870-1874, 2016.

[30] O. Kim, Y. Cho, K. Lee et al., "Introducing EzTaxon-e: a prokaryotic 16s rRNA gene sequence database with phylotypes that represent uncultured species," International Journal of Systematic and Evolutionary Microbiology, vol. 62, no. 3, pp. 716721, 2012.

[31] R. Rosselló-Móra and R. Amann, "Past and future species definitions for Bacteria and Archaea," Systematic and Applied Microbiology, vol. 38, no. 4, pp. 209-216, 2015.

[32] H.-J. Lee, S.-I. Han, and K.-S. Whang, "Streptomyces gramineus sp. nov., an antibiotic-producing actinobacterium isolated from bamboo (Sasa borealis) rhizosphere soil," International Journal of Systematic and Evolutionary Microbiology, vol. 62, no. 4, pp. 856-859, 2012.

[33] T. Kawano, T. Hidaka, K. Furihata et al., "Isolation and structures of mono- and di-deacetyl chromomycin antibiotics 02$3 \mathrm{~d}$ and $02-3 \mathrm{~g}$ from streptomyces a vellaneus," The Journal of Antibiotics, vol. 43, no. 1, pp. 110-113, 1990.

[34] T. Hashimoto, M. Kito, and T. Takeuchi, "Ablastmycin, a new antipicularia antibiotic," The Journal of Antibiotics, vol. 2, no. 3, pp. 888-901, 1982.

[35] H. M. Awad and M. O. Germoush, "Molecular and morphological identification of Streptomyces sp. NRC- 88 nova species as $\beta$-lactamase inhibitor for pharmaceutical application," Asian Journal of Pharmaceutical and Clinical Research, vol. 10, no. 10, pp. 376-383, 2017.

[36] D. Sharma, T. Kaur, B. S. Chadha, and R. K. Manhas, "Antimicrobial activity of actinomycetes against multidrug resistant staphylococcus aureus, E. coli and various other pathogens," Tropical Journal of Pharmaceutical Research, vol. 10, no. 6, pp. 801-808, 2011.

[37] I. Saadoun, "Evaluation of the toxicity of Streptomyces aburaviensis (R9) extract towards various agricultural pests," Agricultural Sciences, vol. 02, no. 4, pp. 491-497, 2011.

[38] G. C. Lancini and P. Sensi, "Isolation of 2-acetyl-2decarboxamidotetracycline from cultures of Streptomyces psammoticus," Experientia, vol. 20, no. 2, pp. 83-84, 1964.

[39] K. Fujiwara, H. Tsukamoto, M. Izumikawa et al., "Total synthesis and structure determination of JBIR-108 - A 2-hydroxy2-(1-hydroxyethyl)-2,3-dihydro-3(2H)-furanone Isolated from Streptomyces gramineus IR087Pi-4," The Journal of Organic Chemistry, vol. 80, no. 1, pp. 114-132, 2015.

[40] J. Dai, Y. Liu, Y.-D. Zhou, and D. G. Nagle, "Hypoxia-selective antitumor agents: Norsesterterpene peroxides from the marine sponge Diacarnus levii preferentially suppress the growth of tumor cells under hypoxic conditions," Journal of Natural Products, vol. 70, no. 1, pp. 130-133, 2007.

[41] N. Bunbamrung, A. Dramae, K. Srichomthong, S. Supothina, and P. Pittayakhajonwut, "Streptophenazines I-L from Streptomyces sp. BCC21835," Phytochemistry Letters, vol. 10, no. 1, pp. 91-94, 2014.

[42] J. T. Thumar, K. Dhulia, and S. P. Singh, "Isolation and partial purification of an antimicrobial agent from halotolerant alkaliphilic Streptomyces aburaviensis strain Kut-8," World Journal of Microbiology and Biotechnology, vol. 26, no. 11, pp. 2081-2087, 2010.
[43] A. Hamed-Mohamedin, N. El-Ahmady, A. El-Dayem et al., "Optimization of bioactive metabolites production by a newly isolated marine streptomyces sp. using statistical approach," Biotechnology, vol. 14, no. 5, pp. 211-224, 2015.

[44] P. Sujatha, K. V. V. S. N. Bapi Raju, and T. Ramana, "Studies on a new marine streptomycete BT-408 producing polyketide antibiotic SBR-22 effective against methicillin resistant Staphylococcus aureus," Microbiological Research, vol. 160, no. 2, pp. 119-126, 2005.

[45] S. Raytapadar and A. Paul, "Production of an antifungal antibiotic by Streptomyces aburaviensis 1DA-28," Microbiological Research, vol. 155, no. 4, pp. 315-323, 2001.

[46] K. N. Niladevi, R. K. Sukumaran, N. Jacob, G. S. Anisha, and P. Prema, "Optimization of laccase production from a novel strain-Streptomyces psammoticus using response surface methodology," Microbiological Research, vol. 164, no. 1, pp. 105113, 2009.

[47] S. Pooja, T. Aditi, S. J. Naine, and C. Subathra Devi, "Bioactive compounds from marine Streptomyces sp. VITPSA as therapeutics," Frontiers in Biology, vol. 12, no. 4, pp. 280-289, 2017.

[48] X. Gao, Y. Lu, Y. Xing et al., "A novel anticancer and antifungus phenazine derivative from a marine actinomycete BM-17," Microbiological Research, vol. 167, no. 10, pp. 616-622, 2012.

[49] C. Balachandran, V. Duraipandiyan, and S. Ignacimuthu, "Purification and characterization of protease enzyme from actinomycetes and its cytotoxic effect on cancer cell line (A549)," Asian Pacific Journal of Tropical Biomedicine, vol. 2, no. 1, pp. S392-S400, 2012.

[50] M. S. Abdelfattah, M. I. Y. Elmallah, U. W. Hawas, L. A. ElKassem, and M. A. G. Eid, "Isolation and characterization of marine-derived actinomycetes with cytotoxic activity from the Red Sea coast," Asian Pacific Journal of Tropical Biomedicine, vol. 6, no. 8, pp. 651-657, 2016. 


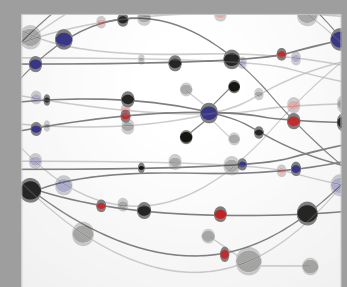

The Scientific World Journal
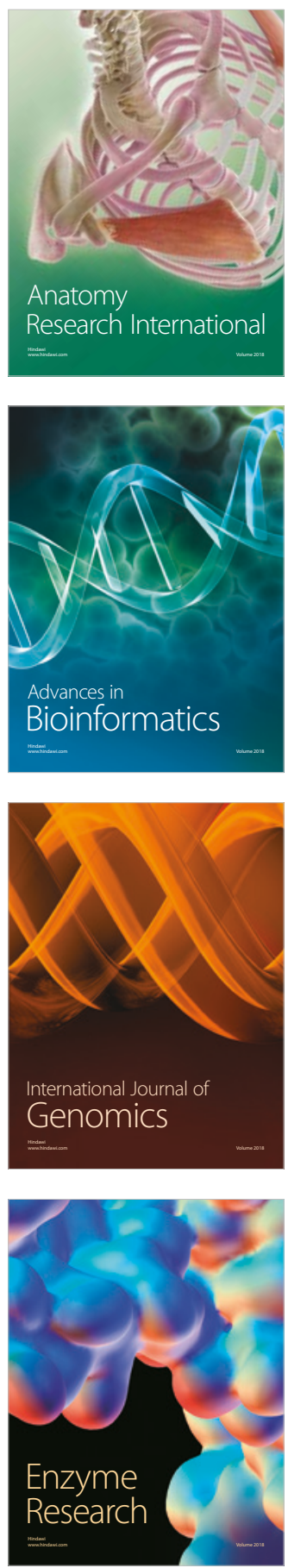
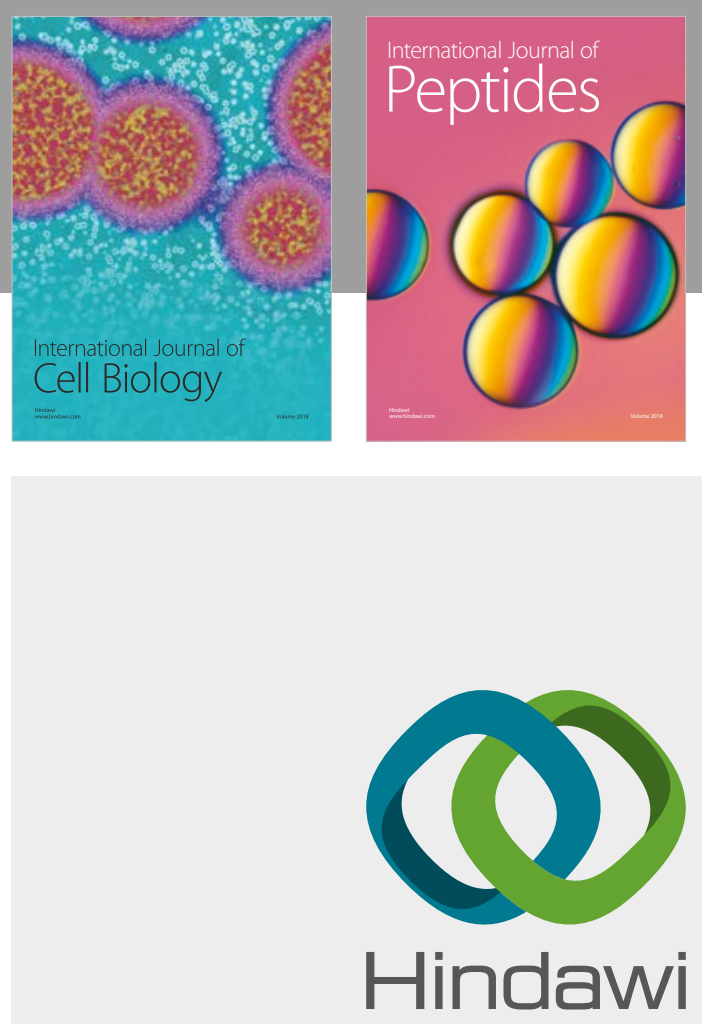

Submit your manuscripts at

www.hindawi.com
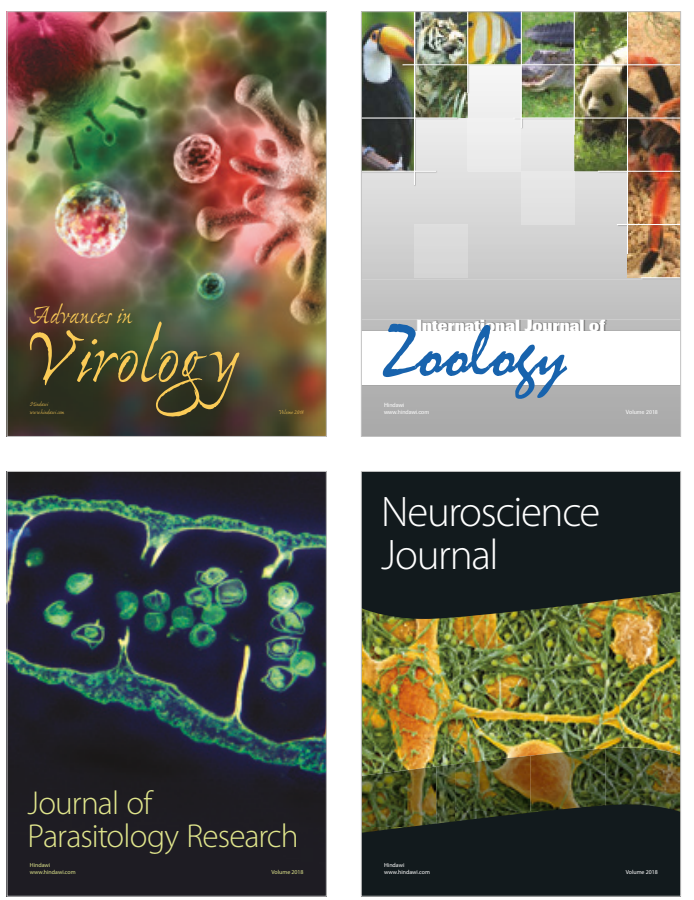
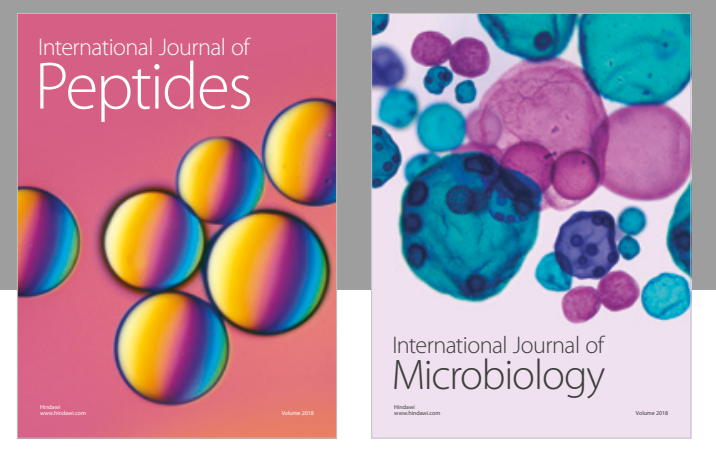

nternational Journal of Microbiology
Journal of
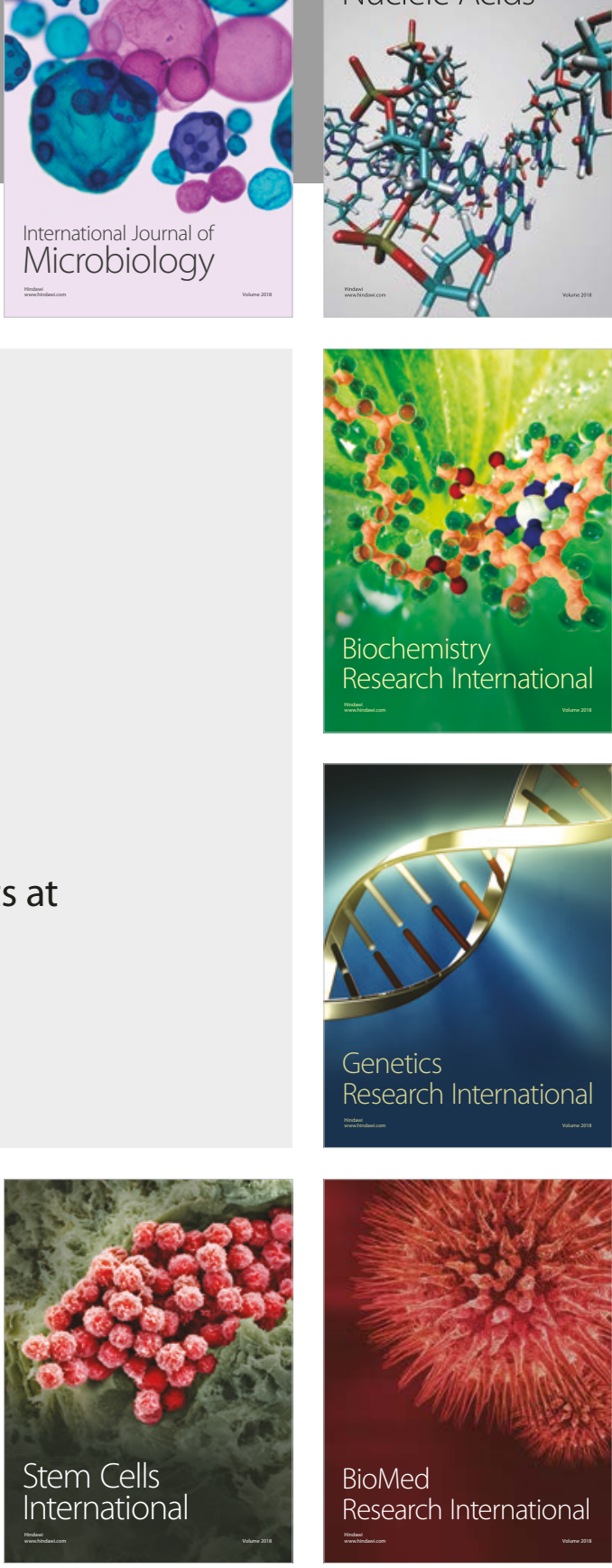
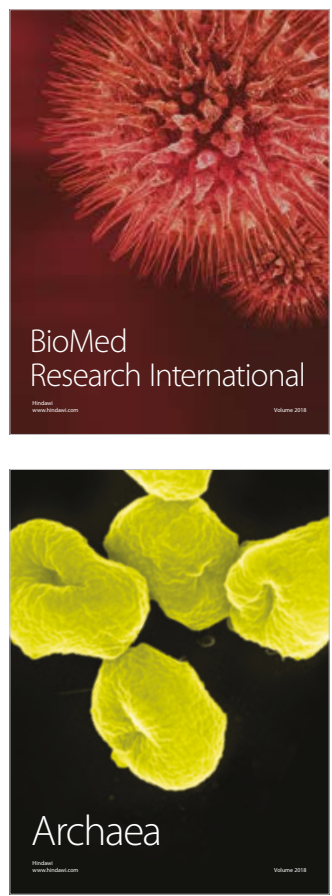